THE UNIVERSITY OF CHICAGO

\title{
EXTERNAL DEBT, CURRENCY RISK, AND INTERNATIONAL MONETARY POLICY TRANSMISSION
}

\author{
A DISSERTATION SUBMITTED TO \\ THE FACULTY OF THE UNIVERSITY OF CHICAGO \\ BOOTH SCHOOL OF BUSINESS \\ IN CANDIDACY FOR THE DEGREE OF \\ DOCTOR OF PHILOSOPHY
}

BY

URSULA WIRIADINATA

CHICAGO, ILLINOIS

JUNE 2018 
Copyright (c) 2018 by Ursula Wiriadinata All rights reserved 
To My Parents 


\section{CONTENTS}

LIST OF FIGURES $\ldots \ldots \ldots \ldots \ldots \ldots \ldots \ldots \ldots \ldots$ vi $\ldots \ldots \ldots \ldots$

LIST OF TABLES $\ldots \ldots \ldots \ldots \ldots \ldots \ldots \ldots$ vii

ACKNOWLEDGEMENT $\ldots \ldots \ldots \ldots \ldots \ldots$ viii

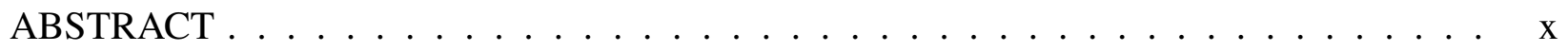

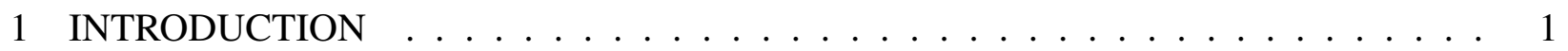

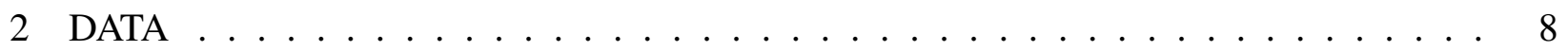

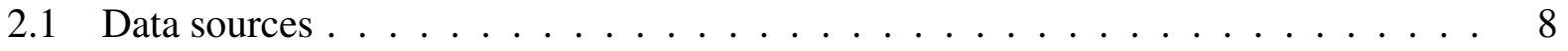

2.2 Identifying U.S. monetary policy shocks . . . . . . . . . . . . . . . 9

3 EMPIRICAL RESULTS . . . . . . . . . . . . . . . . . . . . . . . . 10

3.1 Exchange rate responses to U.S. monetary shocks . . . . . . . . . . . . 10

3.1 .1 Specification . . . . . . . . . . . . . . . . 10

3.1 .2 Main results . . . . . . . . . . . . . . . . . . . . 11

3.1 .3 Main robustness checks . . . . . . . . . . . . . . . . . . . 12

3.1 .4 Other reserve currencies . . . . . . . . . . . . . . . . . . . 13

3.2 Debt issuance responses to U.S. monetary shocks . . . . . . . . . . . . . 14

3.2 .1 Specification . . . . . . . . . . . . . . . . . . 14

3.2 .2 Main results . . . . . . . . . . . . . . . . . . . . . . 15

3.3 Exchange rate movement in flight-to-safety episodes . . . . . . . . . . 15

3.4 Dollar debt, expected returns, and exchange rates $\ldots \ldots \ldots \ldots$

4 MODEL . . . . . . . . . . . . . . . . . . . . . . . . . . . . . 19

4.1 Setup . . . . . . . . . . . . . . . . . . . . . . 19

4.1.1 Environment . . . . . . . . . . . . . . . . . . . . . . . 19

4.1 .2 Market Clearing . . . . . . . . . . . . . . . . . . . . 22

4.1 .3 Solving the model . . . . . . . . . . . . . . . . . . . . . 24

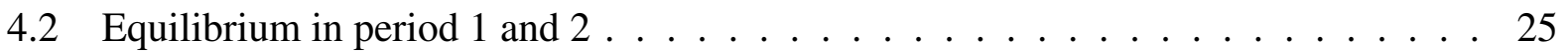

4.2.1 The Effect of U.S. Monetary Shocks on the U.S. Economy . . . . . . . . 25

4.2.2 The Effect of U.S. Monetary Shocks on the Foreign Economy . . . . . . 26

4.3 Equilibrium in period $0 \ldots \ldots \ldots \ldots$

4.3 .1 Currency Risk Premia . . . . . . . . . . . . . . . . . . . . . . 29

4.3.2 Currency Choice of Debt Denomination . . . . . . . . . . . . . 30

4.3 .3 Efficiency . . . . . . . . . . . . . . . . 32

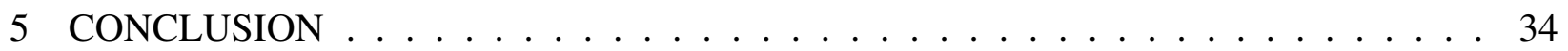




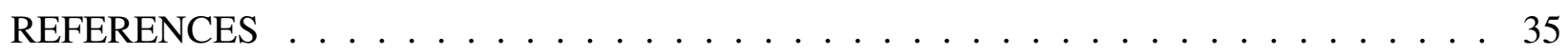

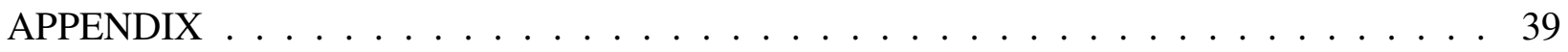

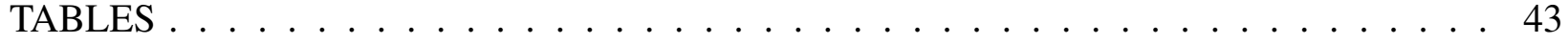

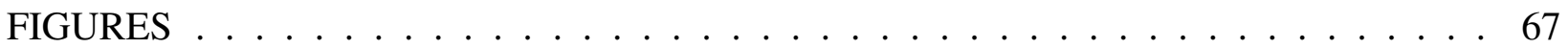




\section{LIST OF FIGURES}

1.1 Exchange-Rate Sensitivities to U.S. Monetary Policy Shocks versus USDebt . . . . 2

1.2 Currency Risk Premia versus USDebt . . . . . . . . . . . . . . . . . . . . 4

4.1 Exposure to U.S. Monetary Shocks vs. Debt-to-GDP Ratios . . . . . . . . . . . 28

4.2 Optimal Domestic-Currency Debt . . . . . . . . . . . . . . . . 32

4.3 The Competitive Market vs. Planner Currency Choice . . . . . . . . . . . . . 33

5.1 Exchange-rate Sensitivities to U.S. Monetary Policy Shocks versus Alternative Measures of Dollar-Debt Level _ . . . . . . . . . . . . . . . . . 67

5.2 The Marginal Impulse Response of USD External Debt Issuance of Countries with USDebt of $25 \% \ldots \ldots \ldots \ldots \ldots$. . . . . . . . . . . . . . . . . . . . . . . 67

5.3 Exchange-Rate Sensitivity to Rare Disasters vs. USDebt . . . . . . . . . . . . . 68

5.4 Exchange-Rate Sensitivity to Rare Disasters vs. USDebt . . . . . . . . . . . . . 69

5.5 One-month Forward Premia versus USDebt . . . . . . . . . . . . . . . . . . . 70

5.6 Time Series of Foreign Central Banks' Policy Rates of Low and High-USDebt countries during the U.S. Quantitative Easing (QE) I and II . . . . . . . . . . . . 71 


\section{LIST OF TABLES}

5.1 Summary Statistics of Countries' External-Debt-to-GDP Ratio . . . . . . . . . . . 43

5.2 Summary Statistics of USDebt Portfolios . . . . . . . . . . . . . . . . . . 44

5.3 List of Currencies in the Sample . . . . . . . . . . . . . . . . . . . . . . . . . . . . .

5.4 Summary Statistics of US Monetary Shocks . . . . . . . . . . . . . . . . . 46

5.5 Responses of Exchange Rates to U.S. Monetary Shocks . . . . . . . . . . . . . . . 47

5.6 Responses of Exchange Rates to U.S. Monetary Shocks . . . . . . . . . . . . . . . 48

5.7 Responses of Exchange Rates to U.S. Monetary Shocks (with Emerging Countries) 49

5.8 Responses of Exchange Rates to U.S. Monetary Shocks (Financial Variables Robustness Checks) . . . . . . . . . . . . . . . . . . . 50

5.9 Responses of Exchange Rates to U.S. Monetary Shocks (Financial Variables Robustness Checks) . . . . . . . . . . . . . . . . . . . 51

5.10 Responses of Exchange Rates to U.S. Monetary Shocks (Macro Variables Robustness Checks) . . . . . . . . . . . . . . . . . . . . . 52

5.11 Responses of Exchange Rates to U.S. Monetary Shocks (Macro Variables Robustness Checks) . . . . . . . . . . . . . . . . . . 53

5.12 Responses of Exchange Rates to U.S. Monetary Shocks (by Sector) . . . . . . . . 54

5.13 Responses of Exchange Rates to Monetary Shocks of BOJ and ECB . . . . . . . . 55

5.14 Responses of External Debt Issuance to U.S. Monetary Shocks . . . . . . . . . . 56

5.15 Responses of External Debt Issuance to U.S. Monetary Shocks (with Non-USD

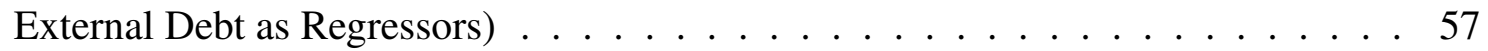

5.16 Responses of International Debt Issuance to U.S. Monetary Shocks (by Currency

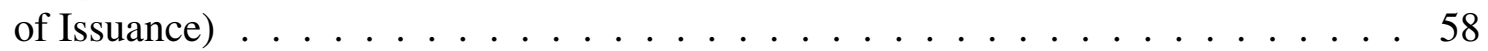

5.17 Responses of International Debt Issuance to U.S. Monetary Shocks (by Sector of Issuer) . . . . . . . . . . . . . . . . . . . . . . . . 59

5.18 Summary Statistics of Exchange Rate Changes around Rare Disasters . . . . . . 60

5.19 USDebt and the Cross-Sectional Variation in Currency Excess Returns . . . . . . 61

5.20 Summary Statistics of Excess Returns of USDebt Portfolios . . . . . . . . . . . 62

5.21 Summary Statistics of Two-day Excess Returns of USDebt Portfolios around the Scheduled FOMC Announcements . . . . . . . . . . . . . . . . 63

5.22 Summary Statistics of Two-day Excess Returns of Different USDebt, Country Size, and Trade Network Centrality Portfolios around the Scheduled FOMC Press

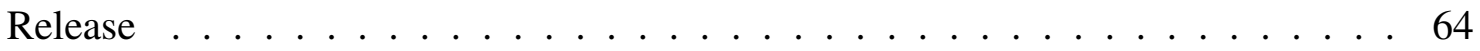

5.23 USDebt, Expected Excess Returns, and Expected Exchange Rate Changes . . . 65

5.24 Summary Statistics of Exchange Rate Changes around the U.S. Large Scale Asset Purchases (LSAP) Announcements . . . . . . . . . . . . . . . 66 


\section{ACKNOWLEDGEMENT}

I have received so much kindness in my life, which has made the impossible possible: earning a $\mathrm{PhD}$ from the University of Chicago and pursuing a professional career in the United States. I owe more people than this page could contain, more than I could remember, and more than I am aware of. I will pass on all the kindness, and hopefully give much more than I undeservedly received.

I am indebted to my advisers, Fernando Alvarez, Tarek Hassan, Brent Neiman, Lubos Pastor, and Michael Weber, for their encouragement and patience and for believing in me even when I was a stubborn, ignorant student with incoherent thoughts. I will always be your student, and hopefully one that you are proud of. My dissertation has benefitted greatly from the stimulating environment at the University of Chicago. I am deeply thankful for the feedback and guidance from Eugene Fama, Stefano Giglio, Lars Hansen, Zhiguo He, Anil Kashyap, Bryan Kelly, Guido Lorenzoni, Raghuram Rajan, and Pietro Veronesi. I am also thankful for the helpful comments from Mark Aguiar, Veronica Guerrieri, Samuel Hartzmark, Greg Kaplan, Casey Mulligan, Laurence Schmidt, Robert Shimmer, Kelly Shue, and Harald Uhlig.

I am beyond grateful to Mark Harris, my undergraduate Economics lecturer. He encouraged me to pursue a master's degree, to which I first dismissed because the only dream I had was to be a housewife, mostly due to my upbringing in a quite conservative society. He elaborately introduced what else I could be, until I finally concurred. Your wisdom and sincerity are a constant reminder for me to be kind and hopeful.

I am deeply thankful to my friends for their endless support. To Gregor and Laura, thank you for the fun trips we had and for the support only true friends could give during my job market. To Jung and Paymon, thank you for listening and actually responding to my random thoughts on so many evenings over the years. To Adam, Agustin, Alex, Ana, Andres, Ben, David, Fran, HK, John, Kerstin, Kow, Peter, Qi, Tony, Triwit, Willem, Yi Nan, Yun Zhi, and all my friends, thank you for sharing the ups and downs and the helpful comments.

To Bobbie Goettler, my editor, thank you for your fantastic advice, for helping my dissertation become readable, and for your understanding in the midst of deadlines.

To my parents, brother, and sister, thank you for your sacrifice and understanding. This dissertation was written during the most difficult time for my family, during which I had the privilege to simply focus on my studies. I would not prevail without your unconditional love. Finally, to Rasool, I am especially grateful for your endless encouragement, support, detailed comments, and 
thoughtful advice throughout the process of my dissertation. You are one of the best things to have happened in my life.

Research support from the Sanford J. Grossman Fellowship in Honor of Arnold Zellner is gratefully acknowledged; any opinions expressed herein are the author's and not necessarily those of Sanford J. Grossman or Arnold Zellner. 


\begin{abstract}
I argue that countries' dollar-denominated net external debt (dollar debt) helps explain the large differences in risk premia across currencies and how U.S. monetary policy affects the global economy. When the U.S. dollar strengthens, the real value of dollar debt increases, weakening the currencies of countries with large amounts of dollar debt and impeding their consumptions. Because the dollar tends to strengthen in bad times, high-dollar-debt currencies are bad hedges and thus have to offer high risk premia. My empirical findings support this idea. First, dollar debt captures exchange-rate and debt-issuance responses to U.S. monetary policy shocks. Second, dollar debt captures the cross-sectional variation in currency risk premia. I develop a general equilibrium model with financial frictions and currency choice of debt denomination that corroborates my findings.
\end{abstract}




\section{CHAPTER 1 \\ INTRODUCTION}

About $60 \%$ of the world's external debt is denominated in U.S. dollars. I argue that countries' dollar-denominated net external debt (dollar debt) creates balance-sheet mismatches that help explain currency risk premia and how U.S. monetary policy affects the global economy. A large literature documents uncovered interest rate parity (UIP) violation; on average, exchange-rate movement does not offset interest-rate differentials between currencies. The cross-sectional violation is economically large and easy to trade. Carry trade - the strategy of investing in high-interest-rate currencies by borrowing in low-interest-rate currencies - gives a Sharpe ratio similar to that in the U.S. stock market. The risk-based explanation is simple: High interest rates reflect risk compensation for lending in currencies that depreciate in bad times. However, although the risk-based explanation is arguably the most accepted, we are still far from fully understanding the mechanisms behind the risk premia.

The main idea of this paper is akin to a standard Fisher's debt deflation. The dollar tends to strengthen after bad news, which means countries with large amounts of ex-ante dollar debt will experience large increases in their real debt burdens, which are negative wealth shocks leading their currencies to depreciate. ${ }^{1}$ The asset-pricing implication is that high-dollar-debt currencies have to offer high risk premia because they are bad hedges. When collateral constraints are binding, the increases in debt burdens will impede consumptions and credit growth. These forces are the backbone of the theoretical framework behind my empirical work.

I perform event studies on two type of events, U.S. monetary policy announcements and rare disasters. These two sources of risks are special. First, they are arguably responsible for about two thirds of average currency excess returns (Barro 2006, Farhi et al. 2009, Mueller et al. 2017). Second, these shocks have direct effects on dollar value through changes in dollar supply and demand for safe assets, respectively. Finally, the availability of high-frequency data on fed funds futures means exogenous monetary policy shocks can be more convincingly identified, which allows me to study causal effects of U.S. monetary policy shocks. My main empirical findings are as follows.

1. Empirically, Gourinchas et al. 2010 shows the dollar strengthens in global downturns. Theoretically, Hassan 2013, He et al. 2015, and Richmond 2016 propose why the dollar is a safe asset. 
First, countries' dollar-denominated net external debt relative to their GDP (USDebt) capture the cross-sectional variation in exchange-rate responses to U.S. monetary policy shocks. As an illustration, Figure 1.1 plots the average exchange-rate movement in two-day windows around FOMC announcements with unexpected cuts in the fed funds rate, against the average USDebt before the events. The unexpected component of fed-funds-rate decisions is identified by changes in the fed-funds-futures rate in 30-minute windows around FOMC announcements. Across all currencies, the average exchange-rate change is positive; an unexpected cut in the fed funds rate is associated with a systematic dollar depreciation. ${ }^{2}$ My finding is the positive slope; higher-USDebt currencies appreciate more against the dollar.

Figure 1.1: Exchange-Rate Sensitivities to U.S. Monetary Policy Shocks versus USDebt

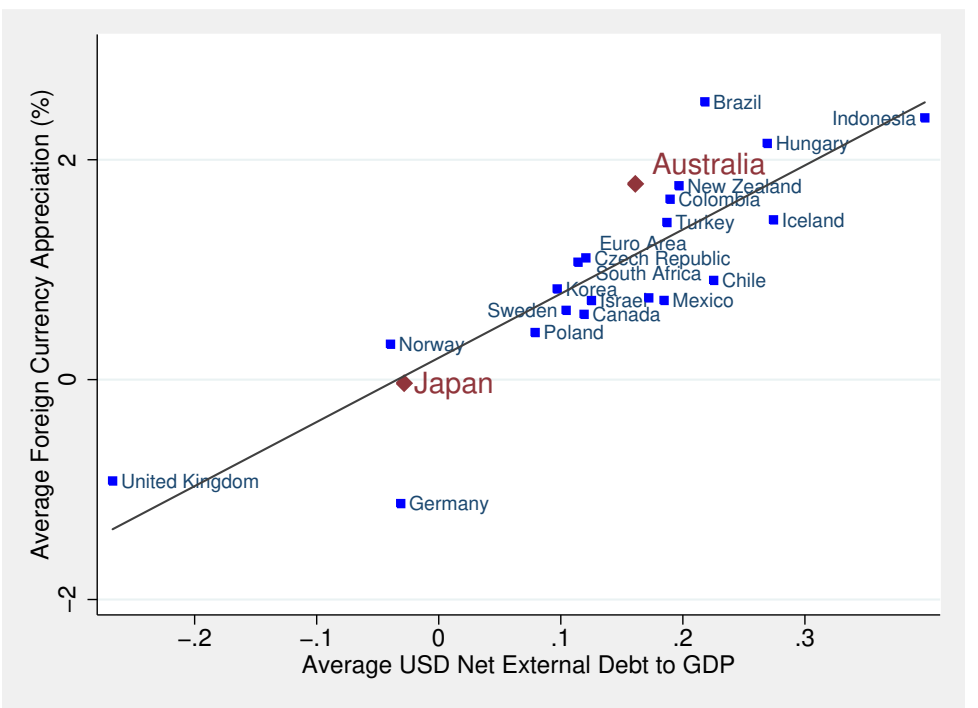

This figure plots the average exchange-rate movement in a two-day window, from day $t-1$ closing price to day $t+1$ closing price, bracketing FOMC announcements with an unexpected cut in the fed-funds rate of five basis points or larger, against the foreign country's average ex-ante USDebt. A positive change in the exchange rate denotes appreciation against the dollar. The sample period is from January 1994 to December 2007.

This cross sectional variation in exchange-rate sensitivities to U.S. monetary shocks is statistically and economically significant. For example, following a one-percentage-point unexpected cut in the fed funds rate, currencies of countries with $25 \%$ USDebt appreciate by $5 \%$ against the

2. The fact that U.S. monetary expansions cause a systematic dollar depreciation is already empirically documented (see, e.g., Eichenbaum and Evans 1995, Andersen et al. 2007 and Faust et al.) and is theoretically founded. 
dollar within two days, whereas zero-USDebt currencies appreciate only by $2 \%$. This pattern also emerges in the time series: A currency becomes more exposed to U.S. monetary shocks when the country's USDebt increases. I decompose each country's debt position into two components: its own time-series average and the deviation from it. Both components are equally significant, statistically and economically.

USDebt captures the first-order cross sectional variation in exchange-rate sensitivities to U.S. monetary shocks. I decompose dollar debt into its gross-assets and gross-liabilities components. Both sides are equally important, statistically and economically. I also decompose net-externaldebt positions by sector of issuers, banking and non-banking, and by maturities. All components are important. The performance of USDebt is robust to controlling for other characteristics. In addition, I do not find evidence that the variation in the exposures is due to foreign monetary policy responses. Finally, I apply the same event-study design to monetary policy announcements by the European Central Bank and the Bank of Japan. I find that euro- and yen-denominated net external debt likewise capture currency exposures to the respective monetary shocks. These results support the idea that the debt deflation channel constitutes an important mechanism for international monetary policy transmission.

Second, after an unexpected cut in the fed funds rate, higher-USDebt countries increase their debt issuance, in both dollars and non-dollars, by larger amounts. For example, countries with $25 \%$ USDebt increase their dollar- and non-dollar debt by 1.5 and 0.6 percentage points, respectively, as a ratio to GDP, within six quarters after a one-percentage-point unexpected cut in the fed funds rate. Meanwhile, I find no evidence that zero-USDebt countries change their debt positions. The debt-issuance response is unrelated to the ex-ante non-dollar external debt. This finding supports the idea that borrowers are credit constrained. Therefore, the exogenous decreases in liabilities lead to credit expansion. This finding offers a mechanism on how U.S. monetary policy may affect the global economy, leading to what is called the "global financial cycle" in Rey 2015.

Third, higher-USDebt currencies depreciate more against the dollar in flight-to-safety episodes. In particular, I consider the LTCM collapse, the 9/11 terrorist attack, and the Lehman Brothers collapse. For example, in the month of the Lehman Brothers collapse, 25\% USDebt currencies depreciated by $15 \%$, while zero-USDebt currencies only depreciated by $5 \%$. I complement these rare-disaster event studies by showing that higher-USDebt currencies are also more sensitive to 
monthly fluctuations in dollar value. ${ }^{3}$

Fourth, higher-USDebt currencies offer higher average currency excess returns, consistent with the idea that currencies that depreciate more in bad times - higher-USDebt currencies - have to offer higher risk premia because they are bad hedges. Figure 1.2 plots the average one-month currency excess return against USDebt in a cross section of countries whose one-month forward exchange rates are traded. I argue that carry trade is risky partly because it invests in high-USDebt currencies by borrowing in low-USDebt currencies. My explanation is consistent with the empirical asset pricing literature that finds a common risk factor in exchange rates (see, e.g., Lustig et al. 2011, Menkhoff et al. 2012, Lettau et al. 2014, and He et al. 2016) and currencies more sensitive to this factor offer higher expected returns, reflected in their higher interest rates.

Figure 1.2: Currency Risk Premia versus USDebt

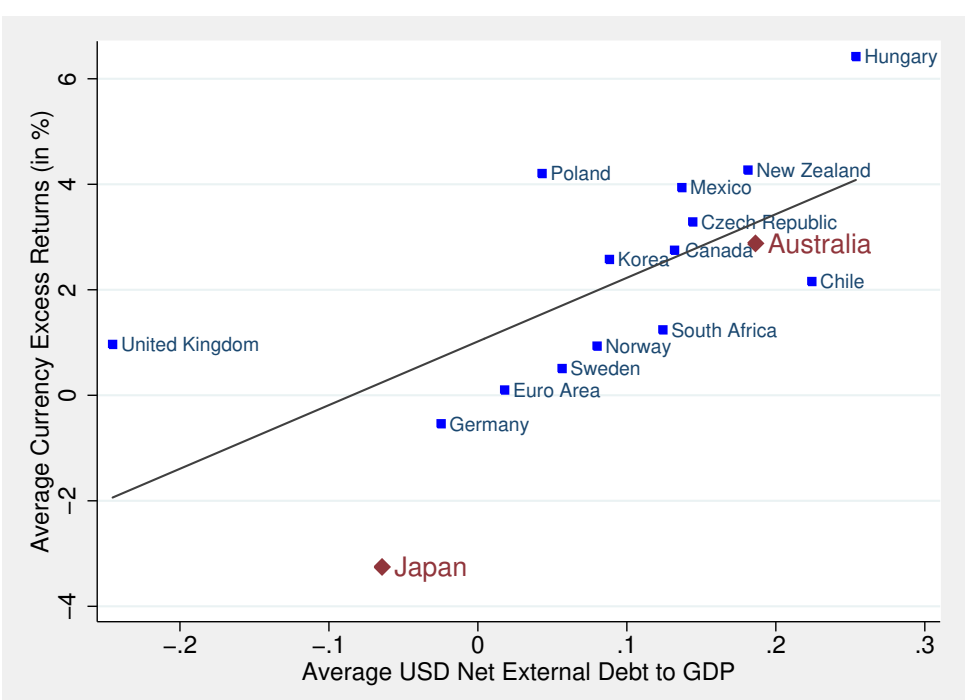

This figure plots average one-month currency excess returns $r x$ against average ex-ante USDebt. $r x$ are measured in USD and based on borrowing 100 USD and investing the fund in a foreign currency. $r x_{t+1}$ is computed as $f_{t}^{1 M}-s_{t+1}$, where $f_{t}^{1 M}$ is the log one-month forward exchange rate at month $t$ and $s_{t+1}$ is the $\log$ spot exchange rate at month $t+1$. By covered interest-rate parity, $r x_{t+1}$ is approximately the one-month interest-rate differential minus USD appreciation during the month, $i_{t}^{*}-i_{t}^{U S D}-\triangle s_{t+1}$. The sample period is from January 1994 to December 2014.

Why do agents borrow? In the cross section of OECD countries, countries with larger USDebt

3. Monthly fluctuation of the dollar is computed as monthly exchange-rate movement of the dollar against a currency basket, representing systematic changes in the dollar value. This dollar fluctuation is also the dollar shock in Lustig et al. 2014 and Verdelhan 2012, who show that dollar risk is priced in the currency market. 
have lower GDP per capita, higher GDP-per-capita growth, and higher share of young population. These correlations are in line with standard motives of borrowing and associated with binding collateral constraints. For example, consumption smoothing means agents with relatively high GDP-per-capita growth tend to borrow from agents with relatively low GDP-per-capita growth. These correlations are also documented in Lane and Milesi-Ferretti 2002.

Why the dollar is the dominant currency of debt denomination is still not clear, especially because its dominance presents in both developed and developing countries (see, e.g., Eichengreen et al. 2002 and Maggiori et al. 2017). In the theoretical part of this paper, I offer a risk-based rationale for why countries choose to borrow in dollars instead of their local currencies.

I develop a qualitative general equilibrium model à la Alvarez et al. 2002 with currency choice of debt denomination. The world consists of two countries, the United States, a large economy, and a small open economy. Each country is endowed with two type of goods, tradable and nontradable. The U.S. asset market is segmented; when the U.S. government injects money through an open market operation, only traders in the U.S. are on the other side of the transaction, and only their marginal utilities determine asset prices. In this type of model, expansionary U.S. monetary shocks increase traders' consumption; therefore, the traders find currencies that appreciate more following the expansionary shocks are riskier.

The effect of U.S. monetary shocks to foreign borrowers is similar to Mendoza 2010. Specifically, for a given dollar debt and collateral constraint (expressed as a maximum debt-to-output ratio), expansionary U.S. monetary shocks lower their real debt burdens, making them richer, increasing domestic demand, increasing the relative price of domestic non-tradable goods, and thus appreciating their currencies.

Why agents borrow in dollars is the following. Foreign agents want to borrow to smooth consumption because they have a high endowment growth. Given a binding collateral constraint, they face a trade-off: Dollar debt allows for higher consumption today because the dollar interest rate is lower, but it leads to higher exposure to U.S. monetary shocks. Initially, when borrowing capacity is low, dollar debt is worth the risk, because the marginal utility of consumption today (the marginal benefit of dollar debt) is high and the marginal increase in exposure (the marginal cost of dollar debt) is low. Subsequently, as borrowing capacity (and thus dollar debt) increases, additional dollar debt is no longer worth the risk, thus borrowers start issuing domestic-currency 
debt. The interior solution exists because utility is concave and exposure to U.S. monetary shocks is convex in dollar debt.

Lastly, I study the efficiency of the currency choice equilibrium. From a second-best perspective, for a given binding debt limit, competitive markets can lead to an excessive dollar borrowing. Atomistic foreign agents do not internalize the effect of U.S. monetary shocks on the country's output value and thus their borrowing capacity. Therefore, they undervalue the insurance from domestic-currency debt which has equity-like payoff.

Related Literatures. This paper relates to a few papers offering an economic explanation for the cross sectional variation in currency risk premia. Hassan 2013, Ready et al. 2013, and Richmond 2016 propose country size, commodity producer, and trade-network centrality, respectively, as the fundamentals behind the risk premia. My paper complements these papers. Empirically, the proposed fundamentals do not diminish the role of USDebt in capturing exchange-rate sensitivities to U.S. monetary shocks and the risk premia. Theoretically, I study distinct sources of risk and transmission mechanisms that can generate currency risk premia.

This paper relates to the literature showing that U.S. monetary policy shocks affect various asset prices (see, e.g., Gurkaynak et al. 2004, Gertler and Karadi 2015, Gorodnichenko and Weber 2016) and there are large unconditional average excess returns earned on FOMC days, which can be interpreted as risk compensation for U.S. monetary policy uncertainty (Savor and Wilson 2014, Lucca and Moench 2015, and Mueller et al. 2017).

This paper relates to the literature on international monetary-policy spillovers. This literature has a large body of studies focusing on the trade channel (see, e.g., Goldberg and Tille 2008, Gopinath et al. 2010, Burstein and Gopinath 2013, and Zhang 2017). My paper relates more closely to studies focusing on the balance-sheet channel (see, e.g., Bernanke and Gertler 1989, Rajan and Zingales 1995, Céspedes et al. 2004, and Cetorelli and Goldberg 2012).

This paper also closely relates to two papers that show the correlation between external wealth and interest rate differentials. Lane and Milesi-Ferretti 2002 is the first to show the correlation between external wealth and interest-rate differentials. Motivated by Gabaix and Maggiori 2014, Della Corte et al. 2016 show their global imbalance risk factor captures the cross-sectional variation 
in currency excess returns. ${ }^{4}$ My paper provides essential additional findings. Empirically, the results from the event studies are new. Theoretically, the mechanisms argued in this paper are distinct.

Lastly, this paper relates to the literature in currency choice of debt denomination (see, e.g., Chamon 2003, Jeanne 2003, Caballero and Krishnamurthy 2003, Korinek 2010, and Bocola and Lorenzoni 2017). Doepke and Schneider 2017 and Gopinath and Stein 2017 show how currency choice of trade invoicing and debt denomination can be complementary. For example, firms with dollar liabilities have an incentive to invoice their exports in dollars. Importantly, empirically, exporters as well as firms without dollar revenue borrow in dollars, and both balance sheet and trade channels are relevant transmission mechanisms (Aguiar 2005, Lane and Shambaugh 2010, Du and Schreger 2016, and Salomao and Varela 2018).

4. External wealth is external assets minus external liabilities in which assets and liabilities include both equity and debt securities. The risk factor is constructed by sorting currencies based on external wealth and the share of liabilities in foreign currencies. 


\section{CHAPTER 2}

\section{DATA}

\subsection{Data sources}

The definitions of debt securities and external positions are based on the guidelines of the International Monetary Fund (IMF). Debt securities include loans, bonds, debentures, certificates of deposit, bills, and notes. External liabilities (assets) are debt issued by residents (nonresidents) and owed to nonresidents (residents), regardless of the market of issuance.

I use the dataset of Lane and Milesi-Ferretti 2007 and Lane and Shambaugh 2010 for countries' external debt and their currency decompositions for all countries except Australia and New Zealand, whose governments publish their own, more detailed, data. I use countries' International Investment Position reports for the sector and maturity decompositions of the external debt. Table 5.1 and 5.2 show the summary statistics of the external debt. The data are annual, reported at the end of every year. Debt-to-GDP ratios are calculated using end-of-year exchange rates. International debt is debt issued under foreign law in international markets. International-debt-issuance data are from Dealogic. The data are quarterly and reported as the dollar equivalent of the face value.

I study currencies of the OECD and big emerging market (EM) countries that adopt flexible exchange rates. I study 22 currencies: 18 OECD and 4 EM countries. Table 5.3 reports the currencies in sample. The baseline period for the U.S. monetary policy event study is from January 1994 to December 2007, during which 112 events occur based on eight scheduled FOMC meetings per year. The United States enters the zero lower bound (ZLB) in December 2008. During the ZLB, fed funds rate has low variation and is not the main monetary policy instrument.

Currencies enter and exit my sample based on their exchange-rate regime in Ilzetzki et al. 2011. I define a flexible exchange-rate currency as one that has variation exceeding a $2 \%$ band around the dollar and other anchor currencies such as the euro. A $2 \%$ band is when the probability that the monthly exchange-rate change remains within a $+/-2 \%$ band over a rolling five-year period is $80 \%$ or higher. For comparison, the probability of monthly JPY/USD exchange-rate changes being within a +/- $2 \%$ band is 30\% in the 1994-2007 period. I exclude currencies during hyperinflation and when they have multiple exchange rates, specifically, when there are large discrepancies 
between the official and market exchange rates.

Spot- and forward-exchange-rates data are from Barclays and Thomson Reuters, available in Datastream. Fed-funds-futures-based measures of U.S. monetary shocks are from Gorodnichenko and Weber 2016. Table 5.4 shows the summary statistics of U.S. monetary shocks.

\subsection{Identifying U.S. monetary policy shocks}

Financial markets are forward-looking, and thus unlikely to respond to anticipated policy news. This behavior makes identifying the unexpected component of the Fed's interest-rate decision crucial. In this paper, I use the method introduced by Kuttner 2001, also used in other papers, such as Bernanke and Kuttner 2005, to calculate the surprise component of the fed-funds-rate decision. The method is based on the changes in the 30-day fed-funds-futures rate in 30-minute windows bracketing the FOMC press releases. The key identifying assumption is that only U.S. monetary policy news moves the fed-funds-futures rate within the 30-minute window around FOMC press releases.

Specifically, the surprise component of the announced fed-funds-rate decision is calculated as

$$
\mu_{t}=\frac{D}{D-t}\left(f f_{t+\triangle t^{+}}^{0}-f f_{t-\triangle t^{-}}^{0}\right)
$$

where $t$ is the time of the FOMC announcement, $f f_{t+\triangle t^{+}}^{0}$ is the fed-funds-futures rate 20 minutes after $t, f f_{t-\triangle t^{-}}^{0}$ is the fed-funds-futures rate 10 minutes before $t, D$ is the number of days in the month, and $D-t$ is the number of days left in the month. The $D /(D-t)$ term adjusts for the fact that the fed funds futures settle on the average effective overnight fed funds rate over the one-month period.

For the high-frequency event study on the effect of U.S. monetary shocks on exchange rates, the measure of U.S. monetary shocks at date $t$ are the shocks identified in the 30-minute window at date $t$. For the study on the effect of U.S. monetary shocks on debt issuance, because debt issuance data are quarterly, I aggregate the shocks identified in the 30-minute window in each quarter to get a quarterly measure of U.S. monetary policy shocks. This aggregation is introduced by Gorodnichenko and Weber 2016 and also used in other papers, such as Gertler and Karadi 2015 and Wong 2016. 


\section{CHAPTER 3 \\ EMPIRICAL RESULTS}

I summarize my four main empirical findings as follows : (1) higher-USDebt currencies are more sensitive to U.S. monetary policy shocks; (2) external-debt issuance of higher-USDebt countries are more sensitive to U.S. monetary policy shocks; (3) during flight-to-safety episodes, higherUSDebt currencies depreciate more against the dollar; and (4) USDebt is significantly correlated with currency excess returns and forward premia, both in the cross section and time series.

\subsection{Exchange rate responses to U.S. monetary shocks}

\subsubsection{Specification}

To test the importance of ex-ante debt positions in explaining the effect of U.S. monetary shocks on exchange rates, I perform an event study on FOMC announcement days and estimate the following panel specification:

$$
\triangle s_{i t}=\beta_{0}+\beta_{\mu} \mu_{t}+\beta_{D e b t}\left[\operatorname{Debt}_{i t-1} \mu_{t}\right]+\gamma_{D e b t} D_{e b t}{ }_{i t-1}+\varepsilon_{i t},
$$

where $\triangle s_{i t}$ is a percentage change in exchange rate defined as currency $i$ per dollar in a oneday window bracketing an event, positive $\triangle s_{i t}$ denotes dollar appreciation, $\mu_{t}$ is a U.S. monetary policy shock, positive $\mu_{t}$ denotes an unexpected fed-funds-rate increase, Debt $t_{t-1}$ is country i's net-external-debt-to-GDP ratio in the year prior to the event, and positive $D e b t_{i t-1}$ denotes a net borrower.

The specification means an one-percentage-point unexpected decrease in the fed funds rate is associated with $\beta_{\mu}+\beta_{D e b t}$ Debt $_{i t-1}$ percent of currency $i$ appreciation against the dollar in the one-day window bracketing an FOMC announcement. I am interested in $\beta_{D e b t}$, which tests the importance of ex-ante debt positions in capturing the effect of U.S. monetary shocks on exchange rates. 


\subsubsection{Main results}

In this section, I discuss the results of the event study on the effects of U.S. monetary shocks on exchange rates. Table 5.5 column (1) shows $\beta_{\mu}$ is positive; an unexpected cut in the fed funds rate causes dollar depreciation against the currency basket. Importantly, $\beta_{\text {Debt }}$ is positive; the foreign-currency appreciation against the dollar is larger for higher-USDebt countries. The $\beta_{\text {Debt }}$ estimate of 7.4 implies a hypothetical one-percentage-point unexpected cut in the fed funds rate is associated with around a $2 \%$ appreciation against the dollar for a country with a zero USDebt, and around $3.5 \%$ for a country with a $25 \%$ USDebt in the one-day window.

In column (2), I add countries' net external debt denominated in non-dollars (NonUSDebt) as

regressors. $\beta_{\text {NonUSDDebt }}$ is significant, but the point estimate is half of $\beta_{U S D D e b t}$. This result indicates the importance of the dollar-debt-deflation channel, because, although all borrowers gain from a lower real refinancing rate regardless of the currency denomination of their debt, only borrowers with a dollar-debt position gain from dollar depreciation.

In column (3), I decompose net dollar-debt position (USDebt) into its gross liabilities and assets components. The coefficient estimate on the gross liabilities is positive, whereas that of gross assets is negative. The sign means higher dollar liabilities are associated with a larger appreciation against the dollar for a given expansionary shock, whereas higher dollar assets are associated with a smaller appreciation. The absolute magnitudes are statistically indistinguishable. These results indicate the importance of the dollar-debt-deflation channel, because to the first order, this channel predicts symmetric yet opposite effects of gross assets and liabilities. In other words, the net position should capture the first-order effect.

In Table 5.6, I decompose each country's USDebt into its time-series average and the deviation from it to test the importance of the cross sectional and time series variation of USDebt in capturing exchange-rate sensitivities to U.S. monetary shocks. The results show both components are equally important, statistically and economically. That is, higher dollar debt in both dimensions is associated with equally larger exchange-rate exposure to the shocks.

In Table 5.7, I add EM currencies to the sample. Comparing the results of columns (2) and (4), I find the sensitivities to U.S. monetary shocks captured by USDebt are significant, although capturing the effect on EM currencies requires a two-day window. The fact that EM currencies are less liquid and less flexible in terms of the degree of exchange-rate flexibility may explain the 
longer event window. I do not find significant changes or reversal in the exchange-rate responses beyond the two-day window.

\subsubsection{Main robustness checks}

In this section, I show the importance of USDebt in capturing exchange-rate sensitivities to U.S. monetary shocks is robust to controlling for other potentially important variables.

Financial variables. In Table 5.8 column (1), I add the expected component of the changes in the fed funds rate as regressors. The coefficients associated with the expected component are not significant, whereas the coefficients associated with the surprise component are about the same as in the baseline specification. This result is consistent with forward-looking financial markets and supports a causal effect of U.S. monetary shocks on exchange rates.

In column (2), I add one-month forward premia as regressors. I find the forward premia do not capture exchange-rate exposures to U.S. monetary shocks after controlling for USDebt. Furthermore, the point estimate and significance of $\beta_{U S D e b t}$ remain stable. The sample size is smaller than the baseline's because of the availability of forward rates. This result shows USDebt performs better in capturing exchange-rate exposures to U.S. monetary shocks.

In column (3), I add one-day changes in one-month forward premia $\triangle r_{t}^{1 M}$ as regressors. The idea is that if the variation in exchange-rate changes on event days is due to variation in foreign interest rates, $\triangle r_{t}^{1 M}$ should absorb the cross country variation and make $\beta_{U S D e b t}$ not significant. The result shows no evidence for this scenario. If foreign central banks control their short-term interest rates, this result also implies my finding is not driven by foreign central-bank monetarypolicy responses. ${ }^{1}$

In column (5) to (8), I control for trade-network centrality (Richmond 2016) and GDP share (Hassan 2013), the macro fundamentals proposed to explain the cross sectional variation in currency risk premia. The results suggest these fundamentals do not drive the variation in the currency exposures captured by USDebt.

1. For more details, in the appendix, I estimate event-study specification (3.1) with changes in foreign short-term rates as the dependent variables. 
Macro variables. In Table 5.8 columns (1) to (3), I control for countries' trade in 3 forms: netexport-to-GDP, dollar-invoiced net-export-to-GDP, and dollar-invoiced gross-export-to-GDP and gross-import-to-GDP ratios separately. The dollar-trade variables are based on the invoice currency pricing data of Gopinath (2015), combined with the trade data from the Penn World Table. The results show the trade variables do not affect the variation in the currency exposures captured by USDebt.

In columns (4) to (8), I control for countries' domestic debt in three forms: domestic-debtto-GDP, government-debt-to-GDP, and non-financial-sector-debt-to-GDP ratios. The results show domestic-debt variables do not affect the variation in the currency exposures captured by USDebt. Because most domestic debt is denominated in domestic currencies, this result supports the importance of the dollar-debt-deflation channel. Theoretically, what could be important is the interaction between dollar debt and domestic debt; for the same USDebt and thus roughly the same initial positive wealth shocks from dollar depreciation, financial frictions can lead to a larger increase in consumption in countries with larger within-country income inequality. The result in column (7) is consistent with this hypothesis.

\subsubsection{Other reserve currencies}

In this section, I discuss the results of performing event studies on the Bank of Japan (BOJ) and European Central Bank (ECB) monetary-policy announcements. I find qualitatively the same result; that is, the currencies of countries with higher amounts of net external debt denominated in the central bank's currency appreciate more against the central-bank currency, after expansionary monetary shocks of the respective central bank.

Table 5.13 shows the results of regression specification 3.1 for the BOJ events. Columns (1) and (2) show that, for both one-day and two-day event windows, the estimate of $\beta_{C B D e b t}$ is positive; the currencies of higher-JPY Debt countries appreciate more against the Japanese yen after BOJ expansionary monetary shocks. For both event windows, the $\beta_{N o n C B D e b t}$ estimate is close to zero; NonJPY Debt does not capture exchange-rate sensitivity to BOJ monetary shocks. $\beta_{C B D e b t}$ is statistically stronger and economically larger for the two-day window. Column (3) shows $\beta_{C B D e b t}$ of the one-day window is also statistically significant when I focus on events with at least two-basispoint changes in the interest rate. The stronger results under the two-day window are consistent 
with the fact that EM currencies are important for the variation in JPY Debt, while EM currencies are relatively slower in reflecting the monetary shocks.

Columns (5) to (8) show the results of the ECB events are qualitatively the same, the currencies of countries with higher EURDebt appreciate more against the euro after ECB expansionary monetary shocks, and no evidence that NonEURDebt captures currency exposures to ECB monetary shocks.

\subsection{Debt issuance responses to U.S. monetary shocks}

\subsubsection{Specification}

To study the importance of ex-ante debt position in capturing how external-debt issuance responds to U.S. monetary shocks, I estimate the following panel specification:

$$
\begin{aligned}
\triangle \text { Debt }_{i, t} & =\sum_{k=0}^{T} \beta_{k} \mu_{t-k}+\sum_{k=0}^{T} \beta_{k, D e b t}\left[\mu_{t-k} \times \text { Debt }_{i, t-k-1}\right]+\sum_{k=0}^{T} \gamma_{k, \text { Debt }}\left[\text { Debt }_{i, t-k-1}\right] \\
& + \text { control }_{i, t-T}+\varepsilon_{i, t}
\end{aligned}
$$

where $\triangle D e b t_{i, t}$ is external-debt issuance of country $i$ in period $t$ normalized by the GDP at the end of $t-1, \mu_{t}$ is U.S. monetary policy shocks in period $t$, and $D e b t_{i, t-k-1}$ is country $i$ 's net-externaldebt-to-GDP ratio at the end of $t-k-1$. One period is a quarter. The baseline control variables are lagged dependent variables of lag 6 to 9, country fixed effects, and quarter fixed effects. This specification allows the debt issuance to respond with lags.

The $T$ quarters cumulative-debt-issuance response, as a ratio to $G D P_{-1}$, of a country with $D_{e b t_{-1}}$ to a one-percentage-point increase in the fed-funds rate is

$$
\triangle \operatorname{Debt}_{i}^{T}=\sum_{k=0}^{T}\left(\beta_{k}+\beta_{k, D e b t} \text { Debt }_{-1}\right)
$$

I am interested in the estimates of $\beta_{k, D e b t}$, because they test the importance of ex-ante debt positions in capturing debt-issuance response to U.S. monetary shocks. 


\subsubsection{Main results}

In this section, I discuss the external-debt-issuance responses to U.S. monetary shocks, and how the responses vary depending on ex-ante external-debt position. Table 5.14 shows high-USDebt -1 countries issue more dollar debt after expansionary monetary shocks. The sum of $\sum_{k=0}^{5} \beta_{k, D e b t}$ is negative and statistically significant. Figure 5.2 plots the estimates, which imply countries with $25 \%$ USDebt $_{-1}$ increase their USDebt by around 1.5 percentage points more than countries with zero $U S D e b t_{-1}$, one year after a one-percentage-point unexpected cut in the fed funds rate. Adding NonUSDebt $_{-1}$ as a regressor, Table 5.15 shows no evidence that NonUSDebt -1 captures the debtissuance response to U.S. monetary shocks.

To examine whether U.S. monetary shocks also affect debt issuance in other currencies, I estimate specification 3.2 with debt issuance in non-dollars as the dependent variables. Table 5.16 shows $\sum_{k=0}^{5} \beta_{k, D e b t}$ is negative, which means, after an expansionary U.S. monetary shock, highUSDebt countries also issue more non-dollar debt. To estimate the total effect of U.S. monetary shocks on the debt issuance, I compute the sum of the common and debt-dependent components $\left(\sum_{k=0}^{5} \beta_{k}+\beta_{k, D e b t} U S D e b t_{-1}\right)$. For countries with $25 \%$ USDebt, a one-percentage-point unexpected cut in the fed-funds rate leads to an increase in dollar- and non-dollar debt-to-GDP ratio by around 1.2 and 0.6 percentage points, within six quarters after the shock, respectively.

To examine which sector in a country responds to U.S. monetary shocks, I estimate specification 3.2 with banking- and non-banking-sector debt issuance as the dependent variables. Table 5.17 shows two interesting results. First, around $66 \%$ of the debt-issuance response in high-debt countries, $\sum_{k=0}^{5} \beta_{k, D e b t}$, is from their banking sector. Second, the banking sector responds faster than the non-banking sector. Specifically, the banking sector responds from the quarter when shocks happen, whereas the non-banking sector responds with a two-quarter lag.

\subsection{Exchange rate movement in flight-to-safety episodes}

In this section, I discuss the cross sectional variation in the exchange-rate movement around the recent flight-to-safety episodes: the Long-Term Capital Management (LTCM) bankruptcy in September 1998 , the terrorist attack on September 11, 2001, and the Lehman Brothers' bankruptcy filing on September 15, 2008. Figure 5.3 plots the exchange-rate movements against USDebt for the later two events. 
To estimate the magnitude of the exchange-rate movements, I allocate currencies to four portfolios based on their USDebt. Figure 5.4 shows the exchange-rate depreciations in these flightto-safety episodes increase monotonically from the lowest to the highest USDebt portfolios. The size of the bubble is a proxy for the severity of the events, a simple average of the decrease in the one-year Treasury yield and S\&P 500 index in the event window. The more severe the disaster, the larger the depreciation.

Table 5.18 shows the summary statistics of exchange-rate movement in the two-business-day and one-month window bracketing the events. The depreciations around these events are economically large. For example, initially, in the two-day window around the Lehman Brothers collapse, the lowest-USDebt currencies barely move while the highest-USDebt currencies depreciate by $2 \%$. As flight to safety escalates, the average and high-minus-low depreciation becomes larger. The lowest-USDebt currencies depreciate by $3 \%$ while the highest-USDebt currencies depreciate by $12 \%$. The same patterns happen around the LTCM collapse and the 9/11 terrorist attacks.

\subsection{Dollar debt, expected returns, and exchange rates}

To illustrate the currency risk implication of USDebt, let us consider the Euler equation of a marginal investor. Currency $i$ 's expected excess return is

$$
E_{t}\left[r x_{i, t+1}\right]=\left(\frac{\operatorname{cov}_{t}\left[m_{t+1}, s_{i, t+1}\right]}{\operatorname{var}_{t}\left[m_{t+1}\right]}\right)\left(\frac{\operatorname{var}_{t}\left[m_{t+1}\right]}{E_{t}\left[m_{t+1}\right]}\right)=\beta_{i, t} \lambda_{t}
$$

where $m_{t+1}$ is the stochastic discount factor at $t+1$, which is proportional to the marginal utility of consumption at $t+1$. An increase in $s_{i, t+1}$ denotes currency $i$ 's real depreciation against the dollar. The second equality is the beta representation, where $\lambda_{t}$ is the price of risk, which is common across currencies, and $\beta_{i, t}$ is the quantity of risk associated with currency $i$. This paper argues $U S D e b t_{i, t}$ partially explains why currencies have different $\beta_{i, t}$. Note that currency $i$ 's expected excess return at $t$ is the forward premium at $t$ minus the expected dollar appreciation $\left(E_{t}\left[r x_{i, t+1}\right]=\right.$ $\left.f p_{i, t}-E_{t}\left[\triangle s_{i, t+1}\right]\right)$. Therefore, in the special case in which the expected exchange-rate movement is constant across currencies, for example, when exchange rates follow a random walk, forward premia summarize the cross-sectional variation in the expected excess returns. 
Cross section. Euler equation (3.3) shows that currencies that depreciate more when marginal utility is high — that is, higher-USDebt currencies — have to offer higher risk premia because they are bad hedges. Table 5.20 shows an empirical pattern consistent with this prediction: the average excess returns from investing in foreign currencies increase monotonically from the lowest- to the highest-USDebt currency portfolios. The USDebt-HML gives an annualized Sharpe ratio of .70, which is the same as if one invests based on forward premia, due to the high correlations between the two.

Table 5.21 reports the average excess returns from investing in the USDebt-HML portfolio for a two-day window around the scheduled FOMC announcements. These two-day FOMC trades give average excess returns that increase monotonically from the lowest- to the highest-USDebt currency portfolios. Table 5.22 reports the returns of the FOMC trades from double-sorted portfolios based on USDebt, country size, and trade-network centrality. The results indicate USDebt performs better in capturing currency risk premia with respect to U.S. monetary policy uncertainty.

Time series. I estimate the panel version of the specification in Fama 1984, with USDebt $t_{i, t}$ as an additional predictor:

$$
\triangle s_{i, t+k}=\alpha_{i}+\beta_{f p p} f p_{i, t, k}+\beta_{D e b t} U S D e b t_{i, t}+\varepsilon_{i, t}
$$

where $\triangle s_{i, t+k}$ is $k$-month exchange-rate changes against the dollar from $t$ to $t+k$, and $U S D e b t_{i, t}$ is simply the dollar debt of country $i$ at the end of the previous year of month $t$. Table 5.23 shows two facts. First, when a country increases its USDebt, the currency pays higher excess returns and is expected to appreciate against the dollar. Second, this time-series relationship is more pronounced for countries with high average USDebt, during high-risk periods, and for longer forecast horizons. USDebt increases the regression fit by around $30 \%$ to a very large increase, because forward premia do not have explanatory power in high-risk periods and for high average USDebt currencies.

To discipline my definition of high-risk periods, I follow Lustig et al. 2014 and define highrisk periods as periods with positive dollar premium. By this definition, high-risk periods include January 1994 to September 1995, May 2001 to April 2005, and February 2008 to December 2014, which are roughly from the beginning of to five years after each U.S. recession.

The better performance of USDebt in predicting returns and exchange rates in high-risks pe- 
riods can be due to time-varying price of risk $\lambda_{t}$, which is increasing in market volatility and risk aversion. Euler equation (3.3) shows the expected returns of currency $i$ vary through time due to its $\beta_{i, t}$ as well as $\lambda_{t}$. In good times, a small increase in dollar debt is unlikely to lead to expected returns that are higher than the overall time-series average because the $\lambda_{t}$ is low.

Lastly, for countries that exhibit strong trends in their USDebt, I expect their excess returns to follow. The data shows this pattern. Figure 5.5 plots one-month forward premia versus USDebt of Mexico and Iceland, two countries that experience large changes in their USDebt and whose forward rates are available. ${ }^{2}$ I also observe the same pattern for South East Asian countries, which reduce their USDebt over time following their 1998 currency crisis.

2. Using currency forwards is important to isolate the exchange-rate risk-premium component in interest rates. That is, using currency forwards eliminates bond price risk and minimizes default risk, because the trading counterparty is large banks whose default risk is low and not currency specific. 


\section{CHAPTER 4}

\section{MODEL}

I study currency risk premia of small open economies with different external debt. I begin with a two-country, cash-in-advance, endowment economy with three periods $(t=0,1,2)$, a government, and a continuum of households of measure 1. The two countries are the United States, a large economy, and a small foreign economy. Country size represents total endowment in the country. In each period $t$, each household receives endowments of $y_{T, t}$ units of a freely transportable nonstorable consumption good (henceforth, tradable good) and $y_{N, t}$ units of a non-transportable nonstorable consumption good (henceforth, non-tradable good). The tradable good is common across countries. Foreign households have a high tradable-good endowment growth, which induces them to borrow to smooth consumption. Assets traded are only nominally risk-free bonds denominated in dollars and the foreign currency. The world economy has only one source of uncertainty: shocks to dollar-supply growth in period 1 . The uncertainty is resolved at the beginning of period 1 , and there is no uncertainty in period 2 .

\subsection{Setup}

\subsubsection{Environment}

Utility and endowment. All variables are expressed in per-capita terms. Each household receives deterministic endowments of

$$
\begin{aligned}
& y_{T, 0}=1-g, y_{T, 1}=1, y_{T, 2}=1+g \\
& y_{N, 0}=1, y_{N, 1}=1, y_{N, 2}=1 .
\end{aligned}
$$

U.S. households have $g^{U S}=0$, whereas foreign household have $g^{*}>0$. The utility function is common across countries. Each household maximizes her lifetime expected utility:

$$
U=E_{0}\left[\sum_{t=0}^{2} \log \left(c_{T, t}\right)^{1 / 2}\left(c_{N, t}\right)^{1 / 2}\right],
$$


where $c_{T, t}$ and $c_{N, t}$ are tradable- and non-tradable-good consumption, respectively, subject to her constraints.

Nominal bonds. The only traded securities are one-period nominally risk-free bonds denominated in the two currencies. A bond denominated in currency $J$ is a risk-free claim to one unit of currency $J$ next period. Its real payoff is the amount of tradable good that one unit of currency $J$ delivers at $t+1: \frac{1}{P_{T, t+1}^{J}}$, where $P_{T, t+1}^{J}$ is the nominal price of tradable good in currency $J$ at $t+1$.

Exchange rates. The law of one price in tradable goods determines the nominal exchange rate. The nominal exchange rate of currency $J, s_{t}^{j}$, is the ratio of tradable-good price in currency $J, P_{T, t}^{j}$, to tradable-good price in dollars, $P_{T, t}^{U S D}$,

$$
s_{t}^{j}=\frac{P_{T, t}^{J}}{P_{T, t}^{U S D}},
$$

where higher $s_{t}^{j}$ denotes nominal appreciation of the dollar against currency $J$. The real exchange rate of currency $J$, $\varepsilon_{t}^{J}$, is the ratio of the consumption price index (CPI), which is

$$
\varepsilon_{t}^{J}=\left(\frac{p_{N, t}^{U S}}{p_{N, t}^{J}}\right)^{1 / 2}
$$

where higher $\varepsilon_{t}^{J}$ denotes real appreciation of the dollar against currency $J$, and $p_{N, t}^{U S}$ and $p_{N, t}^{J}$ are non-tradable-good prices (in units of tradable good) in the U.S. and country $J$, respectively. The derivation is in the appendix 5.

Timeline. The timeline follows Lucas 1982. In each period, there are two markets: asset and goods markets. In the asset market, households engage in competitive bond and currency trading. In the goods market, households buy goods using currencies of where the goods are from, and households sell their endowments of goods for currencies.

In each period, before the asset market opens, all governments decide their money supply simultaneously; thus, the stock of currencies in circulation is known to all households before they 
enter the asset market. ${ }^{1}$ The U.S. government changes dollar supply via open market operations. The foreign government changes foreign-currency supply via a lump-sump tax or transfer. At the conclusion of asset trading, households disperse to trade goods using currencies. At the end of the period, households consume and the cash proceeds from selling endowments becomes the currency holdings at the beginning of the next period. At the beginning of period 0 , all households receive lump-sum amounts of currencies that will be absorbed through a lump-sum tax at the end of the last period.

Given this timeline and the presence of bonds earning a positive nominal return in some currencies, households only hold the exact amounts of currencies needed to cover their perfectly predictable current-period good purchases.

U.S. agents. In the U.S., there are two types of households: traders and non-traders. The traders access the securities market, whereas the non-traders do not. Non-traders are hand-tomouth agents: they do not make intertemporal decision; they simply spend all their cash holdings on goods, every period. The traders' date- $t$ period budget constraint, expressed in dollars, is

$$
P_{T, t}^{U S D}\left(c_{T, t}+p_{N, t} c_{N, t}\right)=M_{t-1}^{U S D}-\left(D_{t}^{U S D}-Q_{t}^{U S D} D_{t+1}^{U S D}\right)-\frac{1}{s_{t}^{J}}\left(D_{t}^{J}-Q_{t}^{J} D_{t+1}^{J}\right)
$$

where $s_{t}^{J}$ is the nominal exchange rate and $Q_{t}^{J}$ is the price, expressed in currency $J$, of the oneperiod nominally risk-free bond denominated in currency $J$. The non-traders' date- $t$ period budget constraint is $P_{T, t}^{U S D} c_{T, t}+P_{T, t}^{U S D} p_{N, t} c_{N, t}=M_{t-1}^{U S D}$.

The U.S. government changes date-1 dollar supply through open market operation. Its period budget constraint, expressed in dollars, at $t \geq 1$ is

$$
D_{t}^{U S D}-Q_{t}^{U S D} D_{t+1}^{U S D}-T_{t}^{U S}=\mu_{t} M_{t-1}^{U S D}
$$

where $D_{t}^{U S D}$ is the value of maturing dollar liabilities at $t, T_{t}^{U S}$ is the tax receipt at $t$, and $\mu_{t} M_{t-1}^{U S D}=$ $M_{t}^{U S D}-M_{t-1}^{U S D}$ is the per-capita increase in dollar supply. All taxes associated with the open market operations are paid by the traders.

1. The results will be the same as if I allow the foreign central bank to respond to U.S. monetary shocks before the asset market opens and the foreign central bank targets a stable domestic-currency CPI. 
Foreign agents. In the foreign country, there is only one type of household. The representative foreign household chooses how much to borrow and lend in her currencies and in dollars. Her period- $t$ budget constraint, expressed in dollars, is

$$
\begin{aligned}
\frac{1}{s_{0}^{J}} P_{T, t}^{J}\left(c_{T, t}+p_{N, t} c_{N, t}\right) & =\frac{1}{s_{0}^{J}} P_{T, t}^{J}\left(y_{T, t}+p_{N, t}^{J} y_{N, t}\right)-\left(D_{t}^{U S D}-Q_{t}^{U S D} D_{t+1}^{U S D}\right) \\
& -\frac{1}{s_{0}^{J}}\left(D_{t}^{J}-Q_{t}^{J} D_{t+1}^{J}\right) .
\end{aligned}
$$

She faces a collateral constraint, a maximum amount of gross debt liabilities relative to output. This constraint applies to the total as well as the debt liabilities in each currency, which is realistic when the same collateral can only be used once. For periods 0 and 1 , the maximum face value of the debt outstanding is $\alpha$ of output in period 1. Specifically, the collateral constraint on the total debt, expressed in dollars, is

$$
D_{t+1}^{U S D}+\frac{1}{s_{t}^{J}} D_{t+1}^{J} \leq \alpha\left[P_{T, 1}^{U S D}\left(y_{T, 1}^{j}+p_{N, 1}^{J} y_{N, 1}^{j}\right)\right] \quad t=0,1
$$

This type of borrowing constraint is standard and one common justification is limited enforcement of contracts. $^{2}$

\subsubsection{Market Clearing}

Money market clearing. Because goods must be purchased using local currencies and the cashin-advance constraint is binding, the money market clearing condition in country $J$ is

$$
M_{t}^{J}=P_{T, t}^{J}\left(y_{T, t}^{j}+p_{N, t}^{J} y_{N, t}^{j}\right) \forall J, t
$$

Without loss of generality, I standardize the nominal price of tradable good in period 0 to one unit, for all currencies. I assume the foreign government targets a stable domestic-currency price of

2. The assumption that the right-hand side of the borrowing constraint at both periods 0 and 1 is the same is made for simplicity and does not affect the qualitative results of the model. Essentially, with this borrowing constraint, there is no trend in the amount a foreign agent is allowed to borrow, and this assumption simplifies the analysis considerably, by ensuring the consumption of a constrained borrower at period 1 is always equal to 1 absent any shocks. 
tradable good. ${ }^{3}$

Asset market and goods market clearing. The market clearing conditions for tradable and non-tradable goods are

$$
\begin{aligned}
\theta\left[(1-\phi) c_{T, t}^{N T, U S}+\phi c_{T, t}^{U S}\right]+(1-\theta) c_{T, t}^{j} & =\theta y_{T, t}^{U S}+(1-\theta) y_{T, t}^{j} \forall t \\
(1-\phi) c_{N, t}^{N T, U S}+\phi c_{N, t}^{U S} & =y_{N, t}^{U S} \forall t, \text { and } \\
c_{N, t}^{j} & =y_{N, t}^{j} \forall t
\end{aligned}
$$

where $\theta$ is the size of the U.S. economy, $\phi$ is the share of the traders in the U.S., and $c_{x, t}^{N T, U S}, c_{x, t}^{U S}$ are the good-x consumption of the non-traders and traders, respectively, in the U.S. economy. The bond market clearing conditions are

$$
\begin{aligned}
D_{t+1}^{J, U S} & =-\frac{1}{\phi}\left(\frac{1-\theta}{\theta}\right) D_{t+1}^{J, j} \forall t, \text { and } \\
D_{t+1}^{U S D, U S} & =-\frac{1}{\phi}\left(\frac{1-\theta}{\theta}\right) D_{t+1}^{U S D, j} \forall t,
\end{aligned}
$$

where $D_{t+1}^{J, U S}$ and $D_{t+1}^{J, j}$ are per-capita currency-J-denominated bonds held by the traders and agent $j$, respectively, and $D_{t+1}^{U S D, U S}$ and $D_{t+1}^{U S D, j}$ are per-capita dollar-denominated bonds held by the traders and agent $j$, respectively.

Equilibrium definition. Given the endowments $\left\{y_{N, t}, y_{T, t}\right\}_{t=0}^{2}$ and money supply distribution $\left\{M_{t}\right\}_{t=0}^{2}$, an equilibrium is a vector of asset prices $\left\{Q_{t}\right\}_{t=0}^{2}$, good prices $\left\{P_{T, t}, p_{N, t}\right\}_{t=0}^{2}$, consumption choices $\left\{c_{T, t}, c_{N, t}\right\}_{t=0}^{2}$, asset holdings $\left\{D_{t}\right\}_{t=1}^{2}$, and money holdings $\left\{M_{t}\right\}_{t=0}^{2}$ such that in each period $t \geq 0$, (1) all households maximize their utility subject to their constraints, taking prices and other agents' actions as given, (2) all government budget constraints hold, (3) asset and goods market clear, and (4) the law of one price in tradable good holds.

3. This assumption is not important for the takeaways of the model, but it is convenient because it eliminates expected trends in the nominal exchange rates and thus simplifies the equilibrium expressions. 


\subsubsection{Solving the model}

I solve the model recursively. I first analyze the equilibrium in period 1 and 2 , taking as given the balance-sheet position decided in period 0 , and then I return to period 0 to solve the optimal portfolio and equilibrium asset prices. I begin with the case in which collateral constraints are binding and the U.S. economy is sufficiently large such that the closed-economy solutions of the effect of U.S. monetary shocks on dollar value, U.S. consumption, and real interest rate are good approximations for the open-economy solutions. That is, I solve the model with the size of U.S. economy $\theta=1$. In this case, the effect of U.S. monetary shocks on the U.S. economy is analogous to Alvarez et al. 2001. Throughout, I assume the cash-in-advance constraint binds and real value refers to value in units of tradable goods.

To illustrate the effect of U.S. monetary shocks $\mu$, I log linearize around the equilibrium when $\mu$ equals 0 , which is the following. The nominal price of tradable good in all currencies is 1 , and thus the nominal exchange rate also equals 1 . Both traders and non-traders in the U.S. consume one unit of tradable and non-tradable goods. The real interest rate also equals 1 . With binding collateral constraints, foreign borrowers only roll over their debt, and thus their tradable and non-tradable consumptions equal 1. By the Euler equation $p_{N}=c_{T} / c_{N}$, the real exchange rate equals 1 . Finally, the following lemma is useful in analyzing the effect of U.S. monetary shocks on exchange rates.

Lemma 1. The unexpected real and nominal exchange-rate appreciation of currency $J$ is increasing in the representative agent j's unexpected tradable-good consumption. Specifically,

$$
\begin{aligned}
& d \log \varepsilon^{J}=d \log p_{N}^{U S D}-d \log c_{T}^{j}, \\
& d \log s_{T}^{J} \approx d \log P_{T}^{U S D}-\frac{1}{2} d \log c_{T}^{j} .
\end{aligned}
$$

The intuition for the former is that, given the Cobb-Douglas utility function, higher $c_{T}$ leads to a higher demand for non-tradable good, which means $p_{N}^{J}$ has to increase to clear non-tradable-good market in country $J$. For the latter, given the same amount of currency- $J$ in circulation, higher $p_{N}^{J}$ means lower $P_{T}^{J}$. Finally, higher $p_{N}^{J}$ and lower $P_{T}^{J}$ imply the real and nominal exchange-rate appreciation of currency- $J$, respectively. The proofs are in the appendix. 


\subsection{Equilibrium in period 1 and 2}

\subsubsection{The Effect of U.S. Monetary Shocks on the U.S. Economy}

In this section, I describe how U.S. monetary shocks $(\mu)$ affect dollar value and traders' consumptions, which are important for the equilibrium asset prices. Traders' cash-in-advance constraint in period 1 after open market operations is

$$
P_{T, 1}^{U S D}\left(c_{T, 1}^{U S}+p_{N, 1}^{U S} c_{N, 1}^{U S}\right)=M_{0}^{U S D}+\frac{\mu M_{0}^{U S D}}{\phi},
$$

where $\phi$ is the share of traders in the U.S. economy, $\frac{\mu M_{0}^{U S D}}{\phi}$ is the increase in dollar holding per trader from the open market operations, $c_{T, 1}^{U S}, c_{N, 1}^{U S}$ are tradable- and non-tradable-good consumption of traders in period 1 . The term $\frac{\mu M_{0}^{U S D}}{\phi}$ reflects the feature that only traders participate in the open market operations. In equilibrium, traders' consumption in terms of $\mu$ are $c_{T, 1}^{U S}=\left[\frac{1+\mu / \phi}{1+\mu}\right]$ and $c_{N, 1}^{U S}=\left[\frac{1+\mu / \phi}{1+\mu}\right] \cdot{ }^{4}$ Around $\mu$ equals zero, period-1 unexpected log changes in tradable-good dollar price, and in traders' tradable-good consumption are

$$
\begin{aligned}
d \log P_{T, 1}^{U S D} & =\mu \\
d \log c_{T, 1}^{U S} & =\frac{1-\phi}{\phi} \mu .
\end{aligned}
$$

Expansionary monetary shock $\mu$ leads to a one-to-one increase in the tradable- and non-tradablegood dollar inflation and to an increase in the traders' tradable- and non-tradable-good consumption by $\frac{1-\phi}{\phi} \mu$. Intuitively, the inflation redistributes wealth from non-traders to traders, and $\frac{1-\phi}{\phi} \mu$ is the inflation tax on non-traders per trader.

The real interest rate in period 1 changes because traders' Euler equation, $c_{T, 1}^{U S}=q_{1} c_{T, 2}^{U S}$, has to hold. Intuitively, because expansionary monetary shocks make traders consume more today, the equilibrium real interest rate has to fall. ${ }^{5}$ The effect of U.S. monetary shocks $\mu$ on the real interest

4. The detailed proof is in the appendix 5.

5. Both traders and non-traders enter period 2 with the same money holding of $M_{1}^{U S D}$ from selling endowments in period 1. Although dollar injections through open market operation mean traders have maturing dollar bond of $\triangle M_{1}$ 
rate is

$$
d \log \left(1+r_{1}\right)=-\frac{1-\phi}{\phi} \mu
$$

\subsubsection{The Effect of U.S. Monetary Shocks on the Foreign Economy}

In this section, I describe how U.S. monetary shocks $(\mu)$ affect the foreign economy. From the period budget constraint, we already can see the partial equilibrium effect of expansionary U.S. monetary shocks: dollar inflation (thus a systematic dollar depreciation) increases borrowers' tradable-good consumption by reducing the real debt burdens of dollar debt. To the first order, this channel only affects borrowers with dollar positions. Specifically, the period budget constraint combined with binding collateral constraints and non-tradable-good market clearing gives

$$
c_{T, 1}^{j}=y_{T, 1}^{j}-\underbrace{\left(\frac{D_{1}^{U S D}}{P_{T, 1}^{U S D}}+\frac{D_{1}^{D C}}{P_{T, 1}^{D C}}\right)}_{\text {Real Debt Payment }}+\underbrace{q_{1} \alpha\left(y_{T, 1}^{j}+p_{N, 1}^{D C} y_{N, 1}^{j}\right)}_{\text {Real Debt Issuance }},
$$

where $\frac{D_{1}^{U S D}}{P_{T, 1}^{U S D}}$ and $\frac{D_{1}^{D C}}{P_{T, 1}^{D C}}$ are the real value of dollar and domestic-currency nominal debt due in period $1, q_{1}$ is the real interest rate between period 1 and 2 , and $\alpha\left(y_{T, 1}^{j}+p_{N, 1}^{D C} y_{N, 1}^{j}\right)$ is the real value of debt issued in period 1. Because there is no uncertainty in period 2, bonds denominated in all currencies have the same real interest rate and I can proceed as if real debt is the only asset traded in period 1 .

My framework incorporates another three transmission mechanisms of $\mu$ to foreign consumption: the revaluation of domestic-currency debt, borrowing capacity, and refinancing cost. They clarify how the currency of debt denomination can be important. Log linearizing equation (4.14)

in period 1 , the government also applies an equal amount of lump-sum transfer so that government budget constraint holds. 
around $\mu$ equals 0 gives

$$
\begin{aligned}
d \log \left(c_{T, 1}^{j}\right)= & \underbrace{d_{1}^{U S D, j} d \log \left(P_{T, 1}^{U S D}\right)}_{\text {Revaluation of USD Debt }}+\underbrace{d_{1}^{D C, j} d \log \left(P_{T, 1}^{D C}\right)}_{\text {Revaluation of DC Debt }} \\
+ & \underbrace{\alpha d \log \left(p_{N, 1}^{D C}\right)}_{\text {Revaluation of Borrowing Capacity }}+\underbrace{2 \alpha d \log \left(q_{1}\right)}_{\text {Revaluation of Real Refinancing Cost }}
\end{aligned}
$$

where $d_{1}=D_{1} / E_{0}\left[P_{T, 1}\right]$ is the expected real value of the nominal debt. The real refinancing cost channel is well known; regardless of the currency denomination, borrowers gain from a lower real refinancing cost. My framework shows the importance of debt denomination: The consumption exposure can be small even though the external debt is high if the debt are denominated in domestic currencies, because domestic-currency debt has an equity-like payoff that mitigates the spillover. Intuitively, suppose the real interest rate declines, which then allows for increases in tradable-good consumptions today. However, first, as in Lemma 1, higher $c_{T}$ leads to a lower nominal domesticcurrency price of tradable good, which means the real value of domestic-currency debt increases, offsetting the initial spillover-consumption gain. Second, as in Lemma 1, higher $c_{T}$ leads to a higher borrowing capacity through the higher $p_{N}$, which means the lower consumption gain just discussed also leads to a smaller increase in borrowing capacity, further mitigating the spillover. Third, the smaller increase in borrowing capacity means smaller gains from the lower interest rate, further mitigating the spillover.

Algebraically, combining the effect of $\mu$ on dollar inflation (4.11) and real interest rate (4.13), equation (4.15) gives the equilibrium tradable-good consumption exposure $\left(\beta_{\mu}^{j}\right)$ to U.S. monetary shocks in terms of ex-ante balance sheet:

$$
d \log \left(c_{T, 1}^{j}\right)=\left(\frac{d_{1}^{U S D, j}+d_{1}^{j} \frac{1-\phi}{\phi}}{1-\frac{1}{2} d_{1}^{U S D, j}}\right) \mu=\beta_{\mu}^{j} \mu
$$

Figure (4.1) illustrates the importance of the currency denomination. The figure shows $\beta_{\mu}^{j}$ for different debt-to-GDP ratios $(\alpha)$ when all debt is in dollars and when all debt is in domestic currencies. When external debt is in domestic currencies, variation in leverage leads to a considerably smaller variation in $\beta_{\mu}^{j}$, which suggests the importance of dollar debt as the determinant of $\beta_{\mu}^{j}$, 
consistent with my empirical findings.

Figure 4.1: Exposure to U.S. Monetary Shocks vs. Debt-to-GDP Ratios
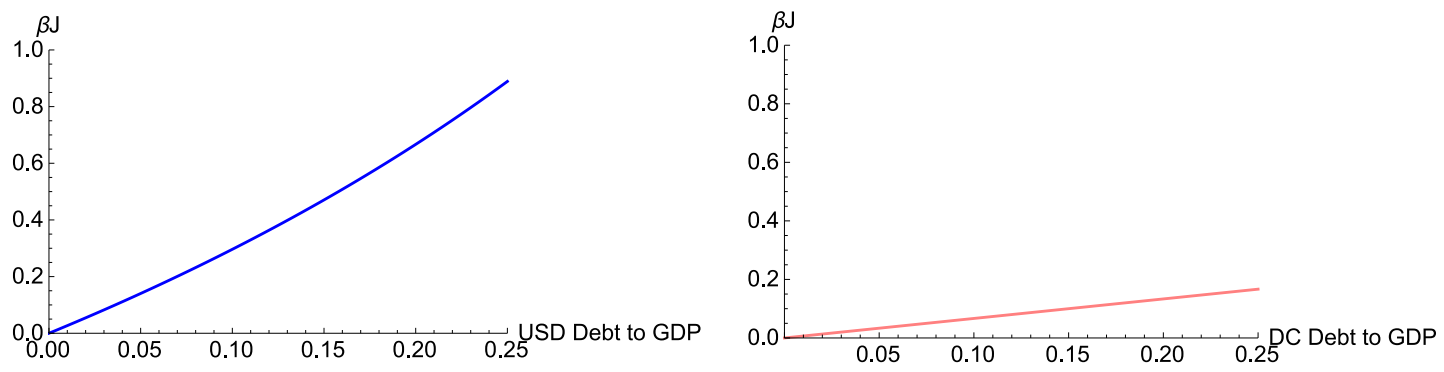

The left and right figures plot equation (4.15) for different maximum-debt-to-GDP ratio $(\alpha)$ when all debt is in dollars and when all debt is in domestic currencies, respectively. Both figures are based on U.S. market segmentation $\left(\frac{1-\phi}{\phi}\right)$ of $\frac{1}{3}$.

My framework generates results consistent with the empirical findings; the exchange rate and debt issuance of higher-dollar-debt countries are more sensitive to U.S. monetary shocks.

Proposition 1. The response of currency- $J$ nominal exchange rate to U.S. monetary shocks $\mu$ is

$$
d \log \left(S_{1}^{J}\right)=\underbrace{(-\mu)}_{\text {Common effect }}+\underbrace{\left(-\frac{1}{2} \beta_{\mu}^{j} \mu\right)}_{\text {Country specific effect }},
$$

where $d \log \left(s_{1}^{J}\right)<0$ denotes currency- $J$ nominal exchange-rate appreciation against the dollar. The first term is the common effect coming from dollar inflation. The second term is the countryspecific effect coming from the effect of $\mu$ on the price of tradable good in currency $J$. Because $\beta_{\mu}^{j}$ is increasing dollar liabilities, larger dollar liabilities $d_{1}^{U S D, j}$ leads to a larger exchange-rate appreciation for a given expansionary shock $\mu$.

Proposition 2. The response of real-debt issuance, as a ratio to the expected output, to an unexpected dollar injection $\mu$ is

$$
\frac{d\left(d_{2}\right)}{E_{0}\left[y_{T, 1}+p_{N, 1} y_{N, 1}\right]}=\frac{1}{2} \beta_{\mu}^{j} \alpha \mu
$$


where $d_{2}$ is the change in the face value of real-debt issuance in period 1 and the denominator is the expected value of output in period 1 . The larger the dollar-debt liabilities $d_{1}^{U S D}$, the larger $\beta_{\mu}^{j}$, and thus the increase in $j$ 's real-debt issuance (relative to the expected output) in response to an unexpected expansionary shocks $\mu$.

\subsection{Equilibrium in period 0}

In this section, I return to period 0 to find the equilibrium currency risk premia and currency choice of debt denomination. Lastly, I proceed with studying the efficiency properties of the competitive equilibrium in my framework.

\subsubsection{Currency Risk Premia}

Because the traders determine asset prices, their Euler equations with respect to all one-period nominally risk-free bonds hold in equilibrium. Specifically, $Q_{0}^{J}=E_{0}\left[\frac{u^{\prime}\left(c_{T, 1}^{U S}\right)}{u^{\prime}\left(c_{T, 0}^{U S}\right)} \frac{P_{T, 0}^{J}}{P_{T, 1}^{J}}\right]$ where $Q_{0}^{J}$ is the period- 0 nominal price, in the domestic currencies, of a one-period nominally risk-free bond paying one unit of the domestic currency of an arbitrary foreign economy $J$. I can express $Q_{0}^{J}$ as

$$
Q_{0}^{J}=\operatorname{Cov}\left(u^{\prime}\left(c_{T, 1}^{U S}\right), \frac{1}{P_{T, 1}^{U S D}}\right)+\operatorname{Cov}\left(u^{\prime}\left(c_{T, 1}^{U S}\right), \frac{1}{s_{T, 1}^{J}}\right)
$$

The price of bonds denominated in riskier currencies - currencies that depreciate more when the trader's marginal utility is high — is lower. Given the effect of U.S. monetary shocks $(\mu)$ on traders' consumption (equation 4.10) and exchange rate (equation 4.17), log linearizing equation (4.19) around $\mu=0$ gives the first-order difference in currency risk premia of dollar bonds and bonds denominated in a foreign currency as a function of the country's balance sheet. 
Proposition 3. The difference in the log expected returns of domestic-currency-J-and dollardenominated nominally-risk-free one-period bonds is

$$
i_{0}^{J}-i_{0}^{U S D}-E_{0}\left[\triangle s_{1}\right]=\underbrace{\left(\beta_{\mu}^{U S}\right)}_{\frac{d \log \left(c_{T, 1}^{U S}\right)}{d \mu}} \underbrace{\left(1+\frac{1}{2} \beta_{\mu}^{j}\right)}_{\frac{d \log \left(s_{1}^{J}\right)}{d \mu}} \sigma_{\mu}^{2},
$$

where $\beta_{\mu}^{U S}$ and $\beta_{\mu}^{j}$ are the sensitivity of the traders' and representative agent j's tradable-good consumption $\left(d \log c_{T, 1}\right)$ to U.S. monetary shocks $\mu$, respectively. The proof is in the appendix 5. The term $i_{0}^{D C}-i_{0}^{U S D}-E_{0}\left[\triangle s_{1}\right]$ is the log expected return, expressed in dollars, of investing in domestic-currency bonds by borrowing in dollar bonds. The expression shows U.S. traders demand high risk premia on bonds denominated in high $\beta_{\mu}^{j}$ currencies, which are the currencies of countries with high dollar debt. When the expected exchange-rate movement is zero, for example, when exchange rates follow a random walk, high currency risk premia translate to high forward premia.

\subsubsection{Currency Choice of Debt Denomination}

In this section, I discuss the optimal currency choice of debt denomination when borrowers face binding collateral constraints. The dominance of dollar debt is stronger when collateral constraints are more binding (that is, borrowing capacity is much smaller than ideal, the debt level if there is no collateral constraint) and when the traders are more exposed to U.S. monetary shocks. The former happens when borrowing capacity is much smaller than endowment growth. The latter happens when the U.S. market is more segmented. The basic ideas are apparent in the first-order 
approximation of foreign agents' Euler equations:

$$
\begin{aligned}
\underbrace{\left(q_{0}^{U S D}-q_{0}^{D C}\right) \frac{c_{T, 1}^{j}}{c_{T, 0}^{j}}}_{\text {Marginal benefit of USD debt }} & \geq \underbrace{\beta_{\mu}^{j}\left(1+\frac{1}{2} \beta_{\mu}^{j}\right) \sigma_{\mu}^{2}}_{\text {Marginal cost of USD debt }} \\
\text { where } c_{T, 0}^{j} & =1-g^{j}+q_{0}^{U S D} 2 \alpha-\left(q_{0}^{U S D}-q_{0}^{D C}\right) d_{1}^{D C, j} \\
\beta_{\mu}^{j} & =\left[\frac{d_{1}^{U S D, j}+2 \alpha \frac{1-\phi}{\phi}}{1-\frac{1}{2} d_{1}^{U S D, j}}\right] .
\end{aligned}
$$

For a given limited borrowing capacity $\alpha$, on the one hand, because dollar debt has a lower interest rate $\left(q_{0}^{U S D}-q_{0}^{j}\right.$ is positive), dollar debt gives a higher tradable-good consumption today $\left(c_{T, 0}^{j}\right)$ and thus a smoother intertemporal consumption, in expectation. On the other hand, dollar debt increases her exposure $\left(\beta_{\mu}^{j}\right)$ to shocks and thus leads to a more volatile consumption. This tradeoff is the key determinant in the optimal currency choice. When borrowing capacity is low, borrowing only in dollars is optimal. The illustration is clear when I give a country with zero international position (autarky) a small amount of borrowing capacity. The marginal benefit of dollar debt is high; borrowing in dollars is cheaper and borrowers' marginal utility of consumption today is high. Whereas the marginal cost of dollar debt is negligible, the effect of dollar debt on $\beta_{\mu}^{j}$ is small when the existing external debt is low. Therefore, borrowing in dollars is optimal. Increasing the borrowing capacity by a small amount and applying the same argument shows that borrowing only in dollars is optimal for a range of borrowing capacity.

However, as dollar debt increases, its marginal benefit declines due to diminishing marginal utility, whereas its marginal cost increases as $\beta_{\mu}^{j}$ is convex in dollar debt. Therefore, under some conditions, the optimal currency choice is interior. In the interior solutions, the risk-sharing wedge between the traders and foreign households $\left(\frac{\beta_{\mu}^{j}}{\beta_{\mu}^{U S}}\right)$ equals the intertemporal wedge in consumption $\left(\frac{\bar{c}_{T, 1}^{j}}{c_{T, 0}^{j}}\right)$,

$$
\frac{\beta_{\mu}^{j}}{\beta_{\mu}^{U S}}=\frac{\bar{c}_{T, 1}^{j}}{c_{T, 0}^{j}} .
$$

Figure 4.2 shows the optimal domestic-currency debt is increasing in borrowing capacity $(\alpha)$ 
and decreasing in the U.S. market segmentation $\left(\frac{1-\phi}{\phi}\right)$. Furthermore, for the same borrowing capacity and market segmentation, countries with more binding collateral constraint - higher $g$ countries - have a wider range of debt-to-GDP ratio such that most liabilities are in dollars, because the interior solution condition (4.22) is met only after a sufficiently high borrowing capacity due borrowers' high intertemporal wedge. The model sheds some light on the original sin: the interaction of risk sharing and limited borrowing capacity may give rise to the ubiquity of dollar debt.

Figure 4.2: Optimal Domestic-Currency Debt
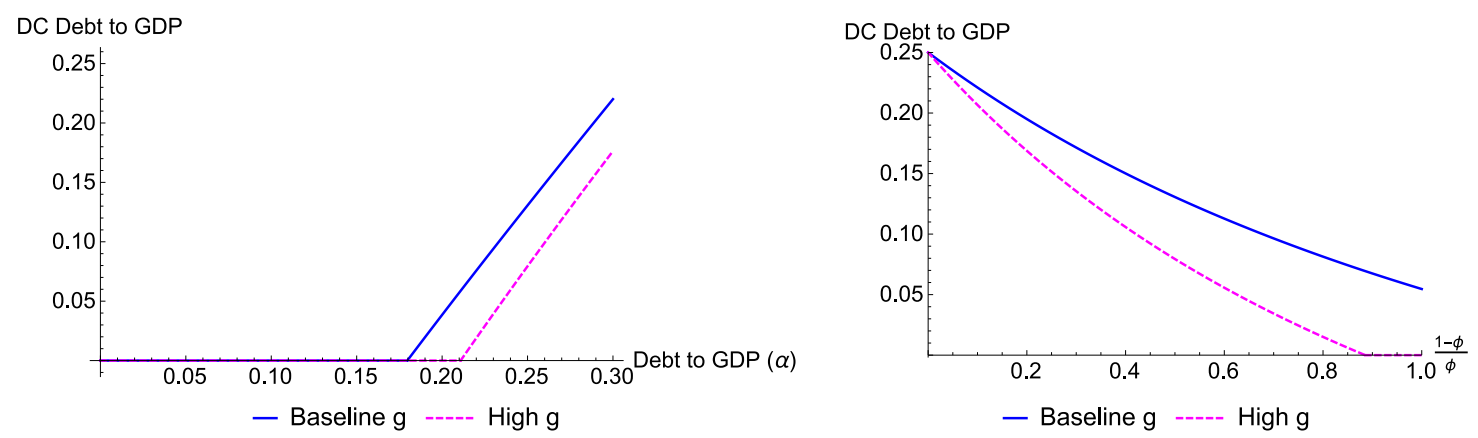

These figures show the domestic-currency (DC) debt-to-GDP ratios that solve equation (4.22). The baseline parameters are U.S. market segmentation $\left(\frac{1-\phi}{\phi}\right)=\frac{1}{2}$, tradable-good growth $(g)=0.6$, variance of $\mu=0.01$, and maximum debt-to-GDP ratio $(\alpha)=0.25$, and the high tradable-good growth $(g)$ is 0.8 .

\subsubsection{Efficiency}

In this section, I solve the second-best currency choice and show that the competitive market equilibrium can lead to an excessive amounts of dollar liabilities. Atomistic individual households undervalue the cost of dollar debt because they do not take into account the effect of their currency choice on the country's output value, which in turn affects their consumption volatilities. A social planner can improve welfare by incorporating this pecuniary externality.

Specifically, the social planner solves foreign households' optimization problem while taking into account the effect of currency choice on the collateral value. The first-order approximation of the planner's Euler equation gives the following condition for an interior solution:

$$
\frac{\bar{c}_{T, 1}^{j}}{c_{T, 0}^{j}}-\frac{\beta_{\mu}^{j}}{\beta_{\mu}^{U S}}=\frac{1}{2} \underbrace{\frac{\partial \beta_{\mu}^{j}}{\partial d_{1}^{U S D, j}}}_{>0} \underbrace{\frac{1}{\left(q_{0}^{U S D}-q_{0}^{D C}\right)}}_{>0}(\underbrace{\beta_{\mu}^{j} d_{1}^{U S D, j}}_{>0}+\underbrace{\beta_{\mu}^{U S} \frac{d_{1}^{D C, j}}{c_{T, 0}^{j}}}_{>0}+\underbrace{\frac{1}{2} \beta_{\mu}^{j} \frac{\left(d_{1}^{U S D, j}+d_{1}^{D C, j}\right)^{2}}{\left(\bar{c}_{T, 2}^{j}\right)^{2}}}_{>0}) \underbrace{2}_{\mu} .
$$


The planner does not equalize the risk-sharing wedge $\left(\frac{\beta_{\mu}^{j}}{\beta_{\mu}^{U S}}\right)$ with the inter-temporal wedge $\left(\frac{\bar{c}_{T, 1}^{j}}{c_{T, 0}^{j}}\right)$, as opposed to the competitive market equilibrium. The term on the RHS is positive, which means the intertemporal rate of substitution is larger than that of the competitive market equilibrium, because the planner chooses higher share of domestic-currency debt and thus reduces the period-0 consumptions in exchange for lower consumption exposure to U.S. monetary shocks.

Figure 4.3 shows how the planner and competitive market domestic-currency debt differ for different debt limits $(\alpha)$ and U.S. market segmentation $\left(\frac{1-\phi}{\phi}\right)$. The domestic-currency liability chosen by the planner is weakly larger than that of the market in both dimensions. As the degree of market segmentation falls, the planner and market solution become closer and finally coincide under no segmentation.

Figure 4.3: The Competitive Market vs. Planner Currency Choice
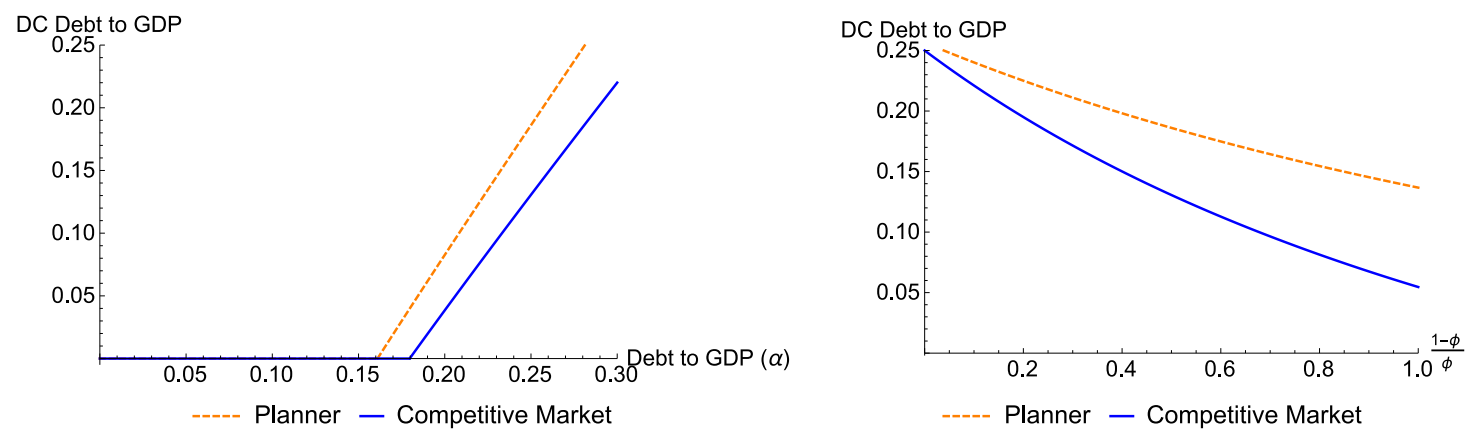

These figures show the domestic-currency (DC) debt-to-GDP ratios of the competitive-market solution (4.22) and the planner solution (4.23). The baseline parameters are U.S. market segmentation $\left(\frac{1-\phi}{\phi}\right)=\frac{1}{2}$, tradable-good growth $(g)=0.6$, variance of $\mu=0.01$, and maximum debt-to-GDP ratio $(\alpha)=0.25$. 


\section{CHAPTER 5}

\section{CONCLUSION}

I offer a novel economic explanation for currency risk premia. Countries' dollar-denominated net external debt (dollar debt) helps explain the large differences in risk premia across currencies and how U.S. monetary policy affects the global economy. When the U.S. dollar strengthens, the real value of dollar debt increases, weakening the currencies of countries with large amounts of dollar debt and impeding their consumptions. Because the dollar tends to strengthen in bad times, high-dollar-debt currencies are bad hedges and thus have to offer high risk premia. My empirical findings support this idea. First, dollar debt captures exchange-rate and debt-issuance responses to U.S. monetary policy shocks. Second, dollar debt captures the cross-sectional variation in currency risk premia. I develop a general equilibrium model with financial frictions and currency choice of debt denomination that corroborates my findings.

My empirical work offers a mechanism of how U.S. monetary policy may affect the global economy, leading to what is called the "global financial cycle" in Rey 2015. My model offers a risk-based rationale for why the dollar is the dominant currency of external-debt denomination, called the "original sin" in Eichengreen et al. 2002. 


\section{REFERENCES}

Mark Aguiar. Investment, Devaluation, and Foreign Currency Exposure: The Case of Mexico. Journal of Development Economics, 78(1):95-113, 2005.

Fernando Alvarez, Robert E Lucas, and Warren E Weber. Interest Rates and Inflation. The American Economic Review, 91(2):219-225, 2001.

Fernando Alvarez, Andrew Atkeson, and Patrick J Kehoe. Money, Interest Rates, and Exchange Rates with Endogenously Segmented Markets. Journal of Political Economy, 110(1):73-112, 2002.

Torben G Andersen, Tim Bollerslev, Francis X Diebold, and Clara Vega. Real-Time Price Discovery in Global Stock, Bond and Foreign Exchange Markets. Journal of International Economics, 73(2):251-277, 2007.

Robert J Barro. Rare Disasters and Asset Markets in the Twentieth Century. The Quarterly Journal of Economics, 121(3):823-866, 2006.

Ben S Bernanke and Mark Gertler. Agency Costs, Net Worth, and Business Fluctuations. American Economic Review, 79(1):14-31, 1989.

Ben S Bernanke and Kenneth N Kuttner. What Explains the Stock Market's Reaction to Federal Reserve Policy? The Journal of Finance, 60(3):1221-1257, 2005.

Luigi Bocola and Guido Lorenzoni. Financial Crises and Lending of Last Resort in Open Economies. Technical report, 2017.

Ariel Burstein and Gita Gopinath. International Prices and Exchange Rates. Technical report, National Bureau of Economic Research, 2013.

Ricardo J Caballero and Arvind Krishnamurthy. Excessive Dollar Debt: Financial Development and Underinsurance. The Journal of Finance, 58(2):867-893, 2003.

Luis Felipe Céspedes, Roberto Chang, and Andres Velasco. Balance Sheets and Exchange Rate Policy. American Economic Review, 94(4):1183-1193, 2004.

Nicola Cetorelli and Linda S Goldberg. Banking Globalization and Monetary Transmission. The Journal of Finance, 67(5):1811-1843, 2012.

Marcos Chamon. Why Can't Developing Countries Borrow from Abroad in Their Currency? 2003.

Pasquale Della Corte, Steven J Riddiough, and Lucio Sarno. Currency Premia and Global Imbalances. Review of Financial Studies, page hhw038, 2016. 
Matthias Doepke and Martin Schneider. Money as a Unit of Account. Econometrica, 85(5):15371574, 2017.

Wenxin Du and Jesse Schreger. Local Currency Sovereign Risk. The Journal of Finance, 71(3): 1027-1070, 2016.

Martin Eichenbaum and Charles L Evans. Some Empirical Evidence on the Effects of Shocks to Monetary Policy on Exchange Rates. The Quarterly Journal of Economics, 110(4):975-1009, 1995.

Barry Eichengreen, Ricardo Hausmann, Ugo Panizza, To JP Morgan, Denis Pêtre, and Martin Anidjar We Are. Original Sin: The Pain, the Mystery, and the Road to Redemption. 2002.

Eugene F Fama. Forward and Spot Exchange Rates. Journal of Monetary Economics, 14(3): 319-338, 1984.

Emmanuel Farhi, Samuel Paul Fraiberger, Xavier Gabaix, Romain Ranciere, and Adrien Verdelhan. Crash Risk in Currency Markets. Technical report, National Bureau of Economic Research, 2009.

Jon Faust, John H Rogers, Shing-Yi B Wang, and Jonathan H Wright. The High-Frequency Response of Exchange Rates and Interest Rates to Macroeconomic Announcements. Journal of Monetary Economics, 54(4):1051-1068, 2007.

Xavier Gabaix and Matteo Maggiori. International Liquidity and Exchange Rate Dynamics. Technical report, National Bureau of Economic Research, 2014.

Mark Gertler and Peter Karadi. Monetary Policy Surprises, Credit Costs, and Economic Activity. American Economic Journal: Macroeconomics, 7(1):44-76, 2015.

Linda S Goldberg and Cédric Tille. Vehicle Currency Use in International Trade. Journal of International Economics, 76(2):177-192, 2008.

Gita Gopinath and Jeremy C Stein. Banking, Trade, and the Making of a Dominant Currency. Technical report, Harvard University, 2017.

Gita Gopinath, Oleg Itskhoki, and Roberto Rigobon. Currency Choice and Exchange Rate PassThrough. The American Economic Eeview, 100(1):304-336, 2010.

Yuriy Gorodnichenko and Michael Weber. Are Sticky Prices Costly? Evidence from the Stock Market. The American Economic Review, 106(1):165-199, 2016.

Pierre-Olivier Gourinchas, Hélène Rey, and Nicolas Govillot. Exorbitant Privilege and Exorbitant Duty. Technical report, 2010.

Refet S Gurkaynak, Brian P Sack, and Eric T Swanson. Do Actions Speak Louder than Words? The Response of Asset Prices to Monetary Policy Actions and Statements. 2004. 
Tarek A Hassan. Country Size, Currency Unions, and International Asset Returns. The Journal of Finance, 68(6):2269-2308, 2013.

Z He, B Kelly, and A Manela. Intermediary Asset Pricing: New Evidence from Many Asset Classes. 2016.

Zhiguo He, Arvind Krishnamurthy, Konstantin Milbradt, et al. A Model of the Reserve Asset. Technical report, 2015.

Ethan Ilzetzki, Carmen M Reinhart, and Kenneth S Rogoff. The Country Chronologies and Background Material to Exchange Rate Arrangements into the 21st Century: Will the Anchor Currency Hold. Available at personal. lse. ac. uk/ilzetzki/data/ERA-Country_Chronologies_2011. pdf(accessed on September 15, 2014), 2011.

Mr Olivier Jeanne. Why Do Emerging Economies Borrow in Foreign Currency? Number 3-177. International Monetary Fund, 2003.

Anton Korinek. Excessive Dollar Borrowing in Emerging Markets: Balance Sheet Effects and Macroeconomic Externalities. 2010.

Kenneth N Kuttner. Monetary Policy Surprises and Interest Rates: Evidence from the Fed Funds Futures Market. Journal of Monetary Economics, 47(3):523-544, 2001.

Philip R Lane and Gian Maria Milesi-Ferretti. Long-Term Capital Movements. In NBER Macroeconomics Annual 2001, Volume 16, pages 73-136. MIT Press, 2002.

Philip R Lane and Gian Maria Milesi-Ferretti. The External Wealth of Nations Mark II: Revised and Extended Estimates of Foreign Assets and Liabilities, 1970-2004. Journal of International Economics, 73(2):223-250, 2007.

Philip R Lane and Jay C Shambaugh. Financial Exchange Rates and International Currency Exposures. The American Economic Review, 100(1):518-540, 2010.

Martin Lettau, Matteo Maggiori, and Michael Weber. Conditional Risk Premia in Currency Markets and Other Asset Classes. Journal of Financial Economics, 114(2):197-225, 2014.

Robert E Lucas. Interest Rates and Currency Prices in a Two-Country World. Journal of Monetary Economics, 10(3):335-359, 1982.

David O Lucca and Emanuel Moench. The Pre-FOMC Announcement Drift. The Journal of Finance, 70(1):329-371, 2015.

Hanno Lustig, Nikolai Roussanov, and Adrien Verdelhan. Common Risk Factors in Currency Markets. Review of Financial Studies, 24(11):3731-3777, 2011.

Hanno Lustig, Nikolai Roussanov, and Adrien Verdelhan. Countercyclical Currency Risk Premia. Journal of Financial Economics, 111(3):527-553, 2014. 
Matteo Maggiori, Brent Neiman, and Jesse Schreger. Unpacking Global Capital Flows. In 2017 Meeting Papers, number 502. Society for Economic Dynamics, 2017.

Enrique G Mendoza. Sudden Stops, Financial Crises, and Leverage. American Economic Review, 100(5):1941-66, 2010.

Lukas Menkhoff, Lucio Sarno, Maik Schmeling, and Andreas Schrimpf. Carry Trades and Global Foreign Exchange Volatility. The Journal of Finance, 67(2):681-718, 2012.

Philippe Mueller, Alireza Tahbaz-Salehi, and Andrea Vedolin. Exchange Rates and Monetary Policy Uncertainty. The Journal of Finance, 72(3):1213-1252, 2017.

Raghuram G Rajan and Luigi Zingales. What Do We Know about Capital Structure? Some Evidence from International Data. The journal of Finance, 50(5):1421-1460, 1995.

Robert Ready, Nikolai Roussanov, and Colin Ward. Commodity Trade and the Carry Trade: A Tale of Two Countries. Technical report, National Bureau of Economic Research, 2013.

Hélène Rey. Dilemma not Trilemma: The Global Financial Cycle and Monetary Policy Independence. Technical report, National Bureau of Economic Research, 2015.

Robert J Richmond. Trade Network Centrality and Currency Risk Premia. SSRN 2607735, 2016.

Juliana Salomao and Liliana Varela. Exchange Rate Exposure and Firm Dynamics. 2018.

Pavel Savor and Mungo Wilson. Asset Pricing: A Tale of Two Days. Journal of Financial Economics, 113(2):171-201, 2014.

Adrien Verdelhan. The Share of Systematic Variation in Bilateral Exchange Rates. 2012.

Arlene Wong. Transmission of Monetary Policy to Consumption and Population Aging. 2016.

Tony Zhang. Monetary Policy Spillovers Through Invoicing Currencies. 2017. 


\section{APPENDIX}

\section{External Debt}

Annual debt-to-GDP ratios. The annual debt-to-GDP ratios are based on debt, GDP, and endof-year exchange rates data from Lane and Milesi-Ferretti 2007 and Lane and Shambaugh 2010. I adjust the debt-to-GDP ratios of Norway as they exhibit considerable amounts of omission; Lane and Milesi-Ferretti 2007 shows that Norway's cumulative net-external-liabilities omission between 1970 and 2004, as a ratio to GDP, is around 28\%. I assume that the omission occurs smoothly between 1970 and 2004 and remains the same after 2004.

Quarterly debt-to-GDP ratios. The quarterly debt-to-GDP ratios are based on GDP data from the OECD and end-of-quarter exchange rates data from Datastream. The evaluation of stock variable is

$$
X_{t}=X_{t-1}\left(1+r_{t}\right)+\text { Flow }_{t}
$$

where. I assume the following. First, the return only consists of exchange rate return. Second, the debt-liabilities flows are from Dealogic and the debt-assets flows are from BIS Locational Banking Statistics. Finally, the end-of-year stock is simply from the annual data.

\section{The effect of U.S. Large Scale Asset Purchase (LSAP) on exchange rates and foreign currency interest rates}

In this section, I study the effect of the U.S. LSAP on exchange rates and foreign currency interest rates. LSAP is different from the conventional monetary policy tool, which is changing the fed-funds target rate, from at least three perspectives, the size of asset purchases, the securities purchased, and the state of the economy when LSAP was introduced.

I find foreign central banks cut their policy rates after LSAP announcements, and the cut is larger for countries with larger USDebt. Figure 5.6 plots central bank policy rates of three groups of countries based on their USD net-external-debt-to-GDP ratios in 2007. The policy rates are normalized to zero on November 1, 2008. Each vertical line indicates LSAP announcement day. The 
larger interest rate cut by larger debt countries is especially apparent after the LSAP announcements on January 28, 2009.

Table 5.24 shows the summary statistics of changes in two-year US treasury yield and exchange rates around LSAP announcements. On average, LSAP announcements are associated with dollar depreciation. Cross sectionally, higher-USDebt currencies experience larger appreciation albeit the pattern is not striking. Foreign central banks' responses to LSAP announcements, as well as, macroeconomic news contained in LSAP might explain the absence of a strong cross-sectional pattern.

\section{Proof}

Real exchange rate The definition of real exchange rate is $\varepsilon_{j, t}=P_{t}^{U S D} /\left(P_{t}^{J} / s_{j, t}\right)$ where $P_{t}$ is the nominal price of consumption bundle in the respective currencies. The real exchange rate is obtained by combining price index definition $P_{t} c_{t}=P_{T, t}\left(c_{T, t}+p_{N, t} c_{N, t}\right)$, consumption bundle definition $c_{t}=c_{T, t}^{1 / 2} c_{N, t}^{1 / 2}$, Euler equation $c_{N, t}=c_{T, t} / p_{N, t}$, and nominal exchange rate $s_{j, t}=P_{T, t}^{J} / P_{T, t}^{U S D}$.

U.S. Trader's consumption By intra-temporal Euler equation, traders spend half their money holding on each good. Because all U.S. households face the same prices, they consume the same bundle. By goods market clearing, the consumption bundle is the same in all periods, $c_{T, t}^{U S} / c_{N, t}^{U S}=$ $y_{T, t}^{U S} / y_{N, t}^{U S}=1$. By the Euler equation $p_{N, t}^{U S}=c_{T, t}^{U S} / c_{N, t}^{U S}$, the non-tradable good real price is also the same in all periods, $p_{N, t}^{U S}=1$. By money market clearing condition (4.3), $p_{N, t}^{U S}=1$, and equation (4.10), we get the traders' consumption in terms of $\mu$.

Equation 4.14 The period budget constraint is

$$
\frac{1}{s_{0}^{J}} P_{T, t}^{D C, J}\left[c_{T, t}^{j}+p_{N, t} c_{N, t}^{j}\right]=\frac{1}{s_{0}^{J}} P_{T, t}^{D C, J}\left[y_{T, t}^{J}+p_{N, t}^{J} y_{N, t}^{J}\right]-\left(D_{t}^{U S D, j}-Q_{t}^{U S D} D_{t+1}^{U S D, j}\right)-\frac{1}{s_{0}^{J}}\left(D_{t}^{D C, j}-Q_{t}^{D C, J} D_{t+1}^{D C, j}\right) .
$$

Substituting the non-tradable good market clearing, we get

$$
\frac{1}{s_{0}^{J}} P_{T, t}^{D C, J}\left[c_{T, t}^{j}\right]=\frac{1}{s_{0}^{J}} P_{T, t}^{D C, J}\left[y_{T, t}^{J}\right]-\left(D_{t}^{U S D, j}-Q_{t}^{U S D} D_{t+1}^{U S D, j}\right)-\frac{1}{s_{0}^{J}}\left(D_{t}^{D C, j}-Q_{t}^{D C, J} D_{t+1}^{D C, j}\right)
$$


Substituting the budget constraint, the definition of nominal exchange rate, and dividing both sides with $P_{T, 1}^{U S D}$, we get

$$
c_{T, t}^{j}=y_{T, t}^{J}-\left(\frac{D_{t}^{U S D, j}}{P_{T, t}^{U S D}}+\frac{D_{t}^{D C, j}}{P_{T, t}^{D C}}\right)+\left(\frac{Q_{t}^{D C, J}}{P_{T, t}^{D C}} D_{t+1}^{D C, j}+\frac{Q_{t}^{U S D}}{P_{T, t}^{U S D}} D_{t+1}^{U S D, j}\right) .
$$

Finally, substituting the definition of real interest rate $Q_{t}=q_{t}\left(P_{T, t} / P_{T, t+1}\right)$, the borrowing constraint $D_{t+1}^{U S D} / P_{T, 1}^{U S D}+D_{t+1}^{D C} / P_{T, 1}^{D C} \leq \alpha\left(y_{T, 1}^{J}+p_{N, 1}^{J} y_{N, 1}^{J}\right)$, and the assumption that all governments set $P_{T, 1}=P_{T, 2}$, we arrive at the expression 4.14 .

Equation 4.16 Substitute 4.11 for $d \log P_{T, 1}^{U S D},-\frac{1}{2} d \log c_{T, 1}$ for $d \log P_{T, 1}^{D C}, 4.13$ for $d \log q_{1}$, and $d \log c_{T, 1}$ for $d \log p_{N, 1}$ in equation (4.16). Finally, use the binding borrowing constraint equation, $d_{1}^{U S D}+d_{1}^{D C}=2 \alpha$.

Equation 4.18 The binding borrowing constraint implies $d_{2}=\alpha\left(y_{T, 1}+p_{N, 1} y_{N, 1}\right)$ and thus $d\left(d_{2}\right)=\alpha\left(d \log p_{N, 1}\right)=\alpha \beta_{\mu}^{j}$. Combined this expression with the expected value of GDP of 2, we arrive to equation (4.18).

\section{Expected excess return}

$$
\begin{aligned}
Q_{0}^{X} & =E_{0}\left[\frac{u^{\prime}\left(c_{T, 1}\right)}{u^{\prime}\left(c_{T, 0}\right)}\left(\frac{P_{T, 0}^{X}}{P_{T, 1}^{X}}\right)\right] \\
\log \left(Q_{0}^{X}\right) & =\log E_{0}\left[u^{\prime}\left(c_{T, 1}\right)\left(\frac{P_{T, 0}^{X}}{P_{T, 1}^{X}}\right)\right]-\log \left(u^{\prime}\left(c_{T, 0}\right)\right) \\
& =\log E_{0}\left[u^{\prime}\left(c_{T, 1}\right)\left(\frac{1}{1+\pi_{T, 1}^{X}}\right)\right]-\log \left(u^{\prime}\left(c_{T, 0}\right)\right) \\
& =\log E_{0}\left[\exp \left(\log u^{\prime}\left(c_{T, 1}\right)-\log \left(1+\pi_{T, 1}^{X}\right)\right)\right]-\log \left(u^{\prime}\left(c_{T, 0}\right)\right)
\end{aligned}
$$

If marginal utilities and inflation are log-normal,

$$
\begin{aligned}
\log \left(Q_{0}^{X}\right) & =E_{0}\left[\log \left(u^{\prime}\left(c_{T, 1}\right)\right)\right]-E_{0}\left[\log \left(1+\pi_{T, 1}^{X}\right)\right] \\
& +\frac{1}{2} \operatorname{Var}\left(\log \left(u^{\prime}\left(c_{T, 1}\right)\right)\right)+\frac{1}{2} \operatorname{Var}\left(\log \left(1+\pi_{T, 1}^{X}\right)\right) \\
& -\operatorname{Cov}\left(\log \left(u^{\prime}\left(c_{T, 1}\right)\right), \log \left(1+\pi_{T, 1}^{X}\right)\right)-\log \left(u^{\prime}\left(c_{T, 0}\right)\right)
\end{aligned}
$$


and the expected return is $E_{0}\left[\left(\frac{P_{T, 0}^{X}}{P_{T, 1}^{X}}\right) / Q_{0}^{X}\right]=\frac{1}{Q_{0}^{X}} E_{0}\left[\frac{1}{1+\pi_{T, 1}^{X}}\right]$, and the log expected return is:

$$
\begin{aligned}
-\log \left(Q_{0}^{X}\right)+\log E_{0}\left[\frac{1}{1+\pi_{T, 1}^{X}}\right] & =-\log \left(Q_{0}^{X}\right)+\log E_{0}\left[\exp \left(-\log \left(1+\pi_{T, 1}^{X}\right)\right)\right] \\
& =-\log \left(Q_{0}^{X}\right)-E_{0}\left[\log \left(1+\pi_{T, 1}^{X}\right)\right]+\frac{1}{2} \operatorname{Var}\left(\log \left(1+\pi_{T, 1}^{X}\right)\right) \\
& =-E_{0}\left[\log \left(u^{\prime}\left(c_{T, 1}\right)\right)\right]+\frac{1}{2} \operatorname{Var}\left(\log \left(u^{\prime}\left(c_{T, 1}\right)\right)\right)+\log \left(u^{\prime}\left(c_{T, 0}\right)\right) \\
& +\operatorname{Cov}\left(\log \left(u^{\prime}\left(c_{T, 1}\right)\right), \log \left(1+\pi_{T, 1}^{X}\right)\right)
\end{aligned}
$$

Define $i^{X}=-\log \left(Q_{0}^{X}\right)$ and $E_{0}\left[\pi_{T, 1}^{X}\right]=-\log E_{0}\left[\frac{1}{\Pi_{T, 1}^{X}}\right]$, then, the difference in log expected return is:

$$
\begin{aligned}
i^{X}-E_{0}\left[\pi_{T, 1}^{X}\right]-\left(i^{U S D}-E_{0}\left[\pi_{T, 1}^{U S D}\right]\right) & =\frac{d \log \left(c_{T, 1}\right)}{d \mu}\left(\frac{d \log \left(1+\pi_{T, 1}^{U S D}\right)}{d \mu}-\frac{d \log \left(1+\pi_{T, 1}^{X}\right)}{d \mu}\right) \sigma_{\mu}^{2} \\
& =\beta_{\mu}^{U S}\left(1+\frac{1}{2} \beta_{\mu}^{*}\right) \sigma_{\mu}^{2}
\end{aligned}
$$

Note that:

$$
\begin{aligned}
-\log \left(Q_{0}^{X}\right)+\log E_{0}\left[\frac{1}{1+\pi_{T, 1}^{X}}\right]+\log \left(Q_{0}^{U S D}\right)-\log E_{0}\left[\frac{1}{1+\pi_{T, 1}^{U S D}}\right] & =i^{X}-i^{U S D}+\log \left(\frac{E_{0}\left[\frac{P_{T, 0}^{X}}{P_{T, 1}^{X}}\right]}{E_{0}\left[\frac{P_{T, 0}^{U S D}}{P_{T, 1}^{U S D}}\right]}\right) \\
& =i^{X}-i^{U S D}-E_{0}\left[\triangle s_{1}^{X}\right]
\end{aligned}
$$




\section{TABLES}

Table 5.1: Summary Statistics of Countries' External-Debt-to-GDP Ratio

This table shows the average and standard deviation of net-external-debt-to-GDP positions of each country in my sample. The sample period is from 1994 to 2014. USD, EUR, JPY, GBP, CHF, and DC stand for the U.S. Dollar, Euro, Japanese Yen, British Pound, Swiss Franc, and domestic currency, respectively.

\begin{tabular}{lccccccc}
\hline Country & \multicolumn{7}{c}{ Net-External-Debt-to-GDP ratios in } \\
& USD & EUR & JPY & GBP & CHF & DC & FC \\
\hline United Kingdom & -0.19 & 0.10 & 0.06 & 0.28 & 0.00 & 0.28 & 0.01 \\
Japan & -0.07 & -0.08 & -0.05 & -0.01 & 0.00 & -0.05 & -0.18 \\
Poland & 0.05 & 0.07 & 0.02 & -0.01 & 0.01 & 0.15 & 0.15 \\
Sweden & 0.06 & 0.14 & 0.06 & -0.02 & 0.02 & 0.19 & 0.32 \\
Euro Area & 0.06 & -0.03 & 0.03 & 0.02 & 0.02 & -0.04 & 0.18 \\
Germany & 0.07 & -0.17 & 0.03 & 0.02 & 0.03 & -0.19 & 0.20 \\
Norway & 0.08 & 0.12 & 0.06 & -0.09 & 0.02 & 0.03 & 0.18 \\
Korea & 0.09 & 0.00 & 0.03 & 0.00 & 0.00 & 0.03 & 0.12 \\
Israel & 0.13 & 0.04 & 0.01 & -0.05 & 0.01 & 0.01 & 0.17 \\
South Africa & 0.14 & -0.01 & 0.00 & -0.03 & 0.00 & 0.03 & 0.09 \\
Canada & 0.14 & 0.01 & 0.02 & 0.00 & 0.01 & 0.18 & 0.19 \\
Brazil & 0.15 & 0.01 & 0.02 & 0.00 & 0.00 & 0.01 & 0.18 \\
Colombia & 0.15 & 0.00 & 0.01 & -0.01 & 0.00 & 0.02 & 0.15 \\
Mexico & 0.15 & 0.00 & 0.02 & 0.00 & 0.00 & 0.00 & 0.17 \\
Czech Republic & 0.16 & -0.06 & 0.01 & -0.02 & 0.00 & 0.00 & 0.04 \\
Hungary & 0.18 & 0.13 & 0.10 & 0.01 & 0.00 & 0.08 & 0.47 \\
Australia & 0.18 & 0.03 & 0.03 & 0.01 & 0.01 & 0.19 & 0.26 \\
New Zealand & 0.19 & 0.01 & 0.02 & 0.02 & 0.01 & 0.32 & 0.29 \\
Turkey & 0.19 & 0.05 & 0.00 & -0.01 & 0.00 & 0.02 & 0.29 \\
Chile & 0.20 & -0.01 & 0.02 & -0.01 & 0.00 & -0.01 & 0.20 \\
Finland & 0.23 & -0.14 & 0.05 & 0.04 & 0.02 & -0.14 & 0.37 \\
Indonesia & 0.29 & 0.02 & 0.13 & 0.00 & 0.00 & 0.02 & 0.49 \\
Iceland & 0.34 & 1.85 & 0.06 & 0.15 & 0.02 & 0.08 & 2.48 \\
\hline
\end{tabular}




\section{Table 5.2: Summary Statistics of USDebt Portfolios}

This table reports, for each portfolio, the average one-month log excess return $r x_{t+1}$ and one-month nominal interest rate differentials implied by log forward premia, $f_{t}-s_{t}$. Log excess returns are computed as $r x_{t+1}=f_{t}-s_{t}-\triangle s_{t+1}$. All moments are annualized and reported in percentage points. The portfolios are constructed by sorting currencies into four groups every beginning of each year based on their USDnet-external-debt-to-GDP ratios (USDebt) in the previous year. DCDebt stands for domestic-currency-netexternal-debt-to-GDP ratios. GDP per capita is expressed in thousands of U.S. dollars. GDP per capita growth is reported in percentage points. The share of young population is the share of population under the age of 50. The young dependency ratio is the number of population under the age of 25 over that of from the age of 25 to 50. Currencies in sample are the currencies of OECD countries with flexible exchange regime. The sample period is from January 1994 to December 2014 for 252 monthly observations and 21 annual observations.

\begin{tabular}{lcccccc}
\hline & Lowest & \multicolumn{5}{c}{ Highest } \\
& USDebt & Port 2 & Port 3 & USDebt & Average & USDebt-HML \\
\hline$r x_{t+1}$ & -0.18 & 1.40 & 3.05 & 5.28 & 2.39 & 5.46 \\
$f p_{t}$ & -0.15 & 1.74 & 2.66 & 5.76 & 2.50 & 5.91 \\
$\triangle s_{t+1}$ & 0.03 & 0.34 & -0.39 & 0.48 & 0.12 & 0.45 \\
Standard deviation & 6.43 & 6.69 & 6.61 & 8.08 & 6.02 & 6.99 \\
Sharpe ratio & -0.03 & 0.21 & 0.46 & 0.65 & 0.40 & 0.78 \\
USDebt $t$ & -0.07 & 0.08 & 0.15 & 0.26 & 0.11 & 0.32 \\
DCDebt $_{t}$ & 0.05 & 0.02 & 0.09 & 0.06 & 0.05 & 0.01 \\
GDP per capita $_{t}$ & 36.5 & 28.8 & 26.4 & 18.6 & 27.6 & -17.9 \\
GDP-per-capita growth $_{t}$ & 4.24 & 4.51 & 5.72 & 6.11 & 5.14 & 1.60 \\
Share of young population $_{t}$ & 0.67 & 0.69 & 0.73 & 0.75 & 0.71 & 0.08 \\
Young dependency ratio $_{t}$ & 0.68 & 0.74 & 0.88 & 0.93 & 0.80 & 0.25 \\
Chin-Ito capital & 0.90 & 0.81 & 0.88 & 0.80 & 0.84 & -0.10 \\
openness index $_{t}$ & & & & & & \\
\hline
\end{tabular}


Table 5.3: List of Currencies in the Sample

This table shows the currencies in the sample. Currencies enter and exit my sample based on their exchangerate regime in Ilzetzki, Reinhart, and Rogoff (2011). I define a flexible exchange-rate currency to be one that has variation exceeding a $2 \%$ band around the USD and other anchor currencies, such as EUR.

\begin{tabular}{llrl}
\hline $\mathrm{N}$ & Country & Year in sample & OECD \\
\hline 1 & Australia & $1994-2014$ & Yes \\
2 & Canada & $2002-2014$ & Yes \\
3 & Chile & $2000-2014$ & Yes \\
4 & Czech Republic & $2002-2014$ & Yes \\
5 & Euro Area & $1999-2014$ & Yes \\
6 & Germany & $1994-1998$ & Yes \\
7 & Hungary & $2005-2014$ & Yes \\
8 & Iceland & $2001-2014$ & Yes \\
9 & Israel & $2005-2014$ & Yes \\
10 & Japan & $1994-2014$ & Yes \\
11 & Korea & $1999-2014$ & Yes \\
12 & Mexico & $1996-2014$ & Yes \\
13 & New Zealand & $1994-2914$ & Yes \\
14 & Norway & $1994-2014$ & Yes \\
15 & Poland & $1995-2014$ & Yes \\
16 & Sweden & $1994-2014$ & Yes \\
17 & Turkey & $2003-2014$ & Yes \\
18 & United Kingdom & $1994-2001,2009-2014$ & Yes \\
19 & Brazil & $2000-2014$ & No \\
20 & Colombia & $2000-2014$ & No \\
21 & Indonesia & $1999-2014$ & No \\
22 & South Africa & $1995-2014$ & No \\
& & & \\
\hline
\end{tabular}




\section{Table 5.4: Summary Statistics of US Monetary Shocks}

This table shows the summary statistics of the 30-minute changes in fed funds futures, and one-day changes in three-month, and one-year Treasury yield bracketing the scheduled FOMC press release. The sample period is from January 1994 to December 2007 for a total of 112 events. The 30-minute changes in the fed funds rate are from Weber and Gorodnichenko (2015). The Treasury-yield data are from the Federal Reserve Board.

\begin{tabular}{lrrr}
\hline Instrument & Fed funds & 3M Treasury & 1Y Treasury \\
\hline Mean & -.5 & -1.9 & -1.2 \\
Median & .0 & -1.0 & -1.0 \\
Standard deviation & 5.9 & 5.3 & 5.7 \\
Min & -22.6 & -19.0 & -19.0 \\
Max & 16.3 & 12.0 & 14.0 \\
Correlations & & .7 & .5 \\
Number of observations & 112 & & \\
\hline
\end{tabular}


Table 5.5: Responses of Exchange Rates to U.S. Monetary Shocks

This table shows the regression results of the following specification:

$$
\triangle s_{i, t}=\alpha+\beta_{\mu} \mu_{t}+\beta_{\text {Debt }}\left[\operatorname{Debt}_{i, t-1} \times \mu_{t}\right]+\gamma_{\text {Debt }} \text { Debt }_{i, t-1}+\varepsilon_{i, t}
$$

where $\triangle s_{i, t}$ is the percentage change in the exchange rate in a one-day window bracketing the FOMC press release, positive $\triangle s_{i, t}$ is USD appreciation, $\mu_{t}$ is the measure of a US monetary policy shock based on fed funds futures, $U S D D e b t_{i, t-1}$ is USD-net-external-debt-to-GDP ratio of country $i$ in the year prior to event $t, U S D$ GrossDebt $L b_{i, t-1}$ is the USD-gross-external-debt-liabilities-to-GDP ratio, USD GrossDebtAs $s_{i, t-1}$ is the USD-gross-external-debt-assets-to-GDP ratio. NonUSD denotes external debt in non-USD. The sample is from January 1994 to December 2007 for a total of 112 events. The sample consists of the OECD currencies with flexible exchange rates. Standard errors are clustered at the event level and reported in parentheses. ${ }^{* *}, * *$, and $*$ denote significance at the $1 \%, 5 \%$, and $10 \%$ levels, respectively.

\begin{tabular}{|c|c|c|c|}
\hline & (1) & (2) & (3) \\
\hline$\mu_{t}$ & $2.17 * * *$ & $1.66^{* *}$ & 1.30 \\
\hline & $(0.64)$ & $(0.66)$ & $(0.87)$ \\
\hline$U_{S D D e b t_{i, t-1}} \times \mu_{t}$ & $\begin{array}{c}7.52 * * * \\
(2.81)\end{array}$ & $\begin{array}{c}6.39 * * * \\
(2.05)\end{array}$ & \\
\hline NonUSD Debt $t_{i, t-1} \times \mu_{t}$ & & $\begin{array}{l}2.92 * \\
(1.51)\end{array}$ & \\
\hline USDGrossDebtL $b_{i, t-1} \times \mu_{t}$ & & & $\begin{array}{l}7.17 * * \\
(2.87)\end{array}$ \\
\hline USDGrossDebtAs $s_{i, t-1} \times \mu_{t}$ & & & $\begin{array}{c}-7.05 * * * \\
(1.69)\end{array}$ \\
\hline NonUSD GrossDebt L $b_{i, t-1} \times \mu_{t}$ & & & $\begin{array}{c}2.14 \\
(1.48)\end{array}$ \\
\hline NonUSD GrossDebtAs $s_{i, t-1} \times \mu_{t}$ & & & $\begin{array}{l}-0.42 \\
(2.36)\end{array}$ \\
\hline$U_{S D D e b t_{i, t-1}}$ & $\begin{array}{l}-0.16 \\
(0.14)\end{array}$ & $\begin{array}{l}-0.16 \\
(0.13)\end{array}$ & \\
\hline NonUSD Debt $t_{i, t-1}$ & & $\begin{array}{c}0.03 \\
(0.07)\end{array}$ & \\
\hline USDGrossDebtLb $b_{i, t-1}$ & & & $\begin{array}{c}-0.49 * * \\
(0.21)\end{array}$ \\
\hline USDGrossDebtAs $s_{i, t-1}$ & & & $\begin{array}{c}0.19 \\
(0.13)\end{array}$ \\
\hline NonUSD GrossDebtL $b_{i, t-1}$ & & & $\begin{array}{c}0.09 \\
(0.06)\end{array}$ \\
\hline NonUSD GrossDebtAs $s_{i, t-1}$ & & & $\begin{array}{l}-0.12 \\
(0.08)\end{array}$ \\
\hline Observations & 1,312 & 1,312 & 1,312 \\
\hline$R^{2}$ & 0.05 & 0.06 & 0.06 \\
\hline Number of countries & 18 & 18 & 18 \\
\hline
\end{tabular}


Table 5.6: Responses of Exchange Rates to U.S. Monetary Shocks

This table shows the regression results of the following specification:

$$
\begin{aligned}
\triangle s_{i, t}= & \alpha+\beta_{\mu} \mu_{t}+\beta_{\overline{\text { ebbt }}}\left[\overline{U S D e b}_{i} \times \mu_{t}\right]+\beta_{\text {Dêbt }}\left[\left(U_{S D e b t_{i, t}}-\overline{U S D e b}_{i}\right) \times \mu_{t}\right] \\
& +\gamma_{\overline{D e b t}} \overline{U S D e b t}_{i}+\gamma_{\text {Dêbt }}\left(U S D e b t_{i, t}-\overline{U S D e b t}_{i}\right)+\varepsilon_{i, t}
\end{aligned}
$$

where $\triangle s_{i, t}$ is the percentage change in the exchange rate in a one-day window bracketing the FOMC press release, positive $\triangle s_{i, t}$ is USD appreciation, $\mu_{t}$ is the measure of a US monetary policy shock based on fed funds futures, $\overline{U S D e b t}_{i}$, is the average USD-net-external-debt-to-GDP ratio of country $i$ between 1994 to 2007, and $U S D e b t_{i, t}-\overline{U S D e b t}_{i}$, is the deviation of USDebt ${ }_{i, t}$ from its average. NonUSDebt denotes nonUSD-net-external-debt-to-GDP ratio. The sample is from January 1994 to December 2007 for a total of 112 events. The sample consists of the OECD currencies with flexible exchange rates. Standard errors are clustered at the event level and reported in parentheses. ***,**, and * denote significance at the $1 \%, 5 \%$, and $10 \%$ levels, respectively.

\begin{tabular}{lc}
\hline$\mu_{t}$ & $2.17 * * *$ \\
& $(0.69)$ \\
$\overline{U S D e b} t_{i} \times \mu_{t}$ & $7.39^{* *}$ \\
& $(3.45)$ \\
$\left(U S D e b t_{i, t}-\overline{U S D e b} t_{i}\right) \times \mu_{t}$ & $7.00^{* *}$ \\
& $(3.35)$ \\
$\overline{U S D e b} t_{i}$ & -0.05 \\
& $(0.20)$ \\
$\left(U S D e b t_{i, t}-\overline{U S D e b} t_{i}\right)$ & $-0.42^{*}$ \\
& $(0.22)$ \\
Constant & -0.03 \\
& $(0.05)$ \\
Observations & 1,312 \\
$R^{2}$ & 0.05 \\
Number of countries & 18 \\
\hline
\end{tabular}


Table 5.7: Responses of Exchange Rates to U.S. Monetary Shocks (with Emerging Countries)

This table shows the regression results of the following specification:

$$
\triangle s_{i, t}=\alpha+\beta_{\mu} \mu_{t}+\beta_{\text {Debt }}\left[\operatorname{Debt}_{i, t-1} \times \mu_{t}\right]+\gamma_{\text {Debt }} \operatorname{Debt}_{i, t-1}+\varepsilon_{i, t}
$$

where $\triangle s_{i, t}$ is the percentage change in exchange rate in one-day or two-day windows bracketing the FOMC press release, positive $\triangle s_{i, t}$ is USD appreciation, $\mu_{t}$ is the measure of a US monetary policy shock based on fed funds futures, $U S D D e b t_{i, t-1}$ is the USD-net-external-debt-to-GDP of country $i$ in the year prior to event $t$, NonUSDDebt $t_{i, t-1}$ is the non-USD net-external-debt-to-GDP ratio. The sample is from January 1994 to December 2007 for a total of 112 events. Standard errors are clustered at the event level and reported in parentheses. $* * *, * *$, and $*$ denote significance at the $1 \%, 5 \%$, and $10 \%$ levels, respectively.

\begin{tabular}{|c|c|c|c|c|}
\hline & (1) & (2) & (3) & (4) \\
\hline \multirow[t]{2}{*}{$\mu_{t}$} & $1.66 * *$ & $1.98 * * *$ & $2.20 *$ & $2.66^{*}$ \\
\hline & $(0.66)$ & $(0.69)$ & $(1.21)$ & $(1.35)$ \\
\hline \multirow[t]{2}{*}{ USDDebt $_{i, t-1} \times \mu_{t}$} & $6.39 * * *$ & 3.06 & $9.66 * * *$ & $8.13 * *$ \\
\hline & $(2.05)$ & $(2.60)$ & $(3.37)$ & $(3.75)$ \\
\hline \multirow{2}{*}{ NonUSD Debt $_{i, t-1} \times \mu_{t}$} & $2.92 *$ & $2.41 *$ & $3.09 * *$ & 2.21 \\
\hline & $(1.51)$ & $(1.21)$ & $(1.33)$ & $(1.31)$ \\
\hline \multirow[t]{2}{*}{$U S D D e b t_{i, t-1}$} & -0.16 & -0.10 & -0.24 & -0.15 \\
\hline & $(0.13)$ & $(0.16)$ & $(0.20)$ & $(0.21)$ \\
\hline \multirow[t]{2}{*}{ NonUSDDebt $_{i, t-1}$} & 0.03 & 0.03 & $0.15^{*}$ & 0.12 \\
\hline & $(0.07)$ & $(0.07)$ & $(0.08)$ & $(0.09)$ \\
\hline \multirow[t]{2}{*}{ Constant } & -0.02 & -0.03 & -0.05 & -0.03 \\
\hline & $(0.05)$ & $(0.05)$ & $(0.06)$ & $(0.07)$ \\
\hline Observations & 1,312 & 1,616 & 1,312 & 1,616 \\
\hline$R^{2}$ & 0.06 & 0.04 & 0.06 & 0.05 \\
\hline Number of countries & 18 & 22 & 18 & 22 \\
\hline Event window & One-day & One-day & Two-day & Two-day \\
\hline Sample & OECD & $\mathrm{OECD}+\mathrm{EM}$ & OECD & $\mathrm{OECD}+\mathrm{EM}$ \\
\hline
\end{tabular}


Table 5.8: Responses of Exchange Rates to U.S. Monetary Shocks (Financial Variables Robustness Checks)

This table shows the regression results of the following specification:

$$
\triangle s_{i, t}=\alpha+\beta_{\mu} \mu_{t}+\beta_{\text {Debt }}\left[\operatorname{Debt}_{i, t-1} \times \mu_{t}\right]+\gamma_{\text {Debt }} \operatorname{Debt}_{i, t-1}+\varepsilon_{i, t}
$$

where $\triangle s_{i, t}$ is the percentage change in the exchange rate in a one-day window bracketing the FOMC press release, positive $\triangle s_{i, t}$ is USD appreciation, $\mu_{t}$ is the measure of a US monetary policy shock based on fed funds futures, $U S D D e b t_{i, t-1}$ is USD-net-external-debt-to-GDP ratio of country $i$ in the year prior to event $t$. The sample is from January 1994 to December 2007 for a total of 112 events. The sample consists of the OECD currencies with flexible exchange rates. Standard errors are clustered at the event level and reported in parentheses. $* * *, * *$, and $*$ denote significance at the $1 \%, 5 \%$, and $10 \%$ levels, respectively.

\begin{tabular}{|c|c|c|c|c|}
\hline & (1) & (2) & (3) & (4) \\
\hline$\mu_{t}$ & $\begin{array}{c}2.18 * * * \\
(0.69)\end{array}$ & $\begin{array}{c}2.11 * * * \\
(0.68)\end{array}$ & $\begin{array}{c}2.31 * * * \\
(0.67)\end{array}$ & $\begin{array}{c}2.71 * * \\
(1.05)\end{array}$ \\
\hline$U_{S D D e b t}{ }_{i, t-1} \times \mu_{t}$ & $\begin{array}{c}6.90 * * \\
(2.70)\end{array}$ & $\begin{array}{c}6.74 * * \\
(2.67)\end{array}$ & $\begin{array}{c}8.42 * * * \\
(2.86)\end{array}$ & \\
\hline$E_{t-1}\left[\triangle f f_{t}\right]$ & $\begin{array}{c}0.01 \\
(0.27)\end{array}$ & & & \\
\hline$U_{S D D e b t}{ }_{i, t-1} \times E_{t-1}\left[\triangle f f_{t}\right]$ & $\begin{array}{c}0.70 \\
(0.60)\end{array}$ & & & \\
\hline $1 M$ forward premia ${ }_{i, t-1} \times \mu_{t}$ & & $\begin{array}{c}1.68 \\
(1.26)\end{array}$ & & \\
\hline$\triangle 1 M$ forward premia ${ }_{i, t-1} \times \mu_{t}$ & & & $\begin{array}{l}-14.83 \\
(14.35)\end{array}$ & \\
\hline Trade Centrality $_{i, t-1} \times \mu_{t}$ & & & & $\begin{array}{l}-0.19 \\
(4.30)\end{array}$ \\
\hline Constant & $\begin{array}{l}-0.02 \\
(0.05)\end{array}$ & $\begin{array}{l}-0.03 \\
(0.05)\end{array}$ & $\begin{array}{l}-0.02 \\
(0.05)\end{array}$ & $\begin{array}{c}0.24 \\
(0.31)\end{array}$ \\
\hline Observations & 1,312 & 1,206 & 1,206 & 1,168 \\
\hline$R^{2}$ & 0.05 & 0.06 & 0.06 & 0.04 \\
\hline Number of countries & 18 & 18 & 18 & 14 \\
\hline
\end{tabular}


Table 5.9: Responses of Exchange Rates to U.S. Monetary Shocks (Financial Variables Robustness Checks)

This table shows the regression results of the following specification:

$$
\triangle s_{i, t}=\alpha+\beta_{\mu} \mu_{t}+\beta_{\text {Debt }}\left[\operatorname{Debt}_{i, t-1} \times \mu_{t}\right]+\gamma_{\text {Debt }} \operatorname{Debt}_{i, t-1}+\varepsilon_{i, t}
$$

where $\triangle s_{i, t}$ is the percentage change in the exchange rate in a one-day window bracketing the FOMC press release, positive $\triangle s_{i, t}$ is USD appreciation, $\mu_{t}$ is the measure of a US monetary policy shock based on fed funds futures, $U S D D e b t_{i, t-1}$ is USD-net-external-debt-to-GDP ratio of country $i$ in the year prior to event $t$. The sample is from January 1994 to December 2007 for a total of 112 events. The sample consists of the OECD currencies with flexible exchange rates. Standard errors are clustered at the event level and reported in parentheses. $* * *, * *$, and $*$ denote significance at the $1 \%, 5 \%$, and $10 \%$ levels, respectively.

\begin{tabular}{|c|c|c|c|}
\hline & (5) & (6) & (7) \\
\hline$\mu_{t}$ & $\begin{array}{c}3.18 * * * \\
(0.72)\end{array}$ & $\begin{array}{c}0.87 \\
(1.02)\end{array}$ & $\begin{array}{c}2.51 * * * \\
(0.58)\end{array}$ \\
\hline$U_{S D D e b t_{i, t-1}} \times \mu_{t}$ & & $\begin{array}{c}9.05 * * * \\
(2.52)\end{array}$ & $\begin{array}{c}6.59 * * \\
(2.76)\end{array}$ \\
\hline Trade Centrality $_{i, t-1} \times \mu_{t}$ & & $\begin{array}{l}9.06^{*} \\
(4.23)\end{array}$ & \\
\hline GDP Share $_{i, t-1} \times \mu_{t}$ & $\begin{array}{l}-2.71 * * \\
(1.23)\end{array}$ & & $\begin{array}{l}-1.68^{*} \\
(0.93)\end{array}$ \\
\hline Constant & $\begin{array}{l}-0.04 \\
(0.05)\end{array}$ & $\begin{array}{l}-0.02 \\
(0.05)\end{array}$ & $\begin{array}{c}0.38 \\
(0.36)\end{array}$ \\
\hline Observations & 1,312 & 1,312 & 1,168 \\
\hline$R^{2}$ & 0.04 & 0.05 & 0.05 \\
\hline Number of countries & 18 & 18 & 14 \\
\hline
\end{tabular}


Table 5.10: Responses of Exchange Rates to U.S. Monetary Shocks (Macro Variables Robustness Checks)

This table shows the regression results of the following specification:

$$
\triangle s_{i, t}=\alpha+\beta_{\mu} \mu_{t}+\beta_{\text {Debt }}\left[\operatorname{Debt}_{i, t-1} \times \mu_{t}\right]+\gamma_{\text {Debt }} \operatorname{Debt}_{i, t-1}+\varepsilon_{i, t}
$$

where $\triangle s_{i, t}$ is the percentage change in the exchange rate in a one-day window bracketing the FOMC press release, positive $\triangle s_{i, t}$ is USD appreciation, $\mu_{t}$ is the measure of a US monetary policy shock based on fed funds futures, $U S D D e b t_{i, t-1}$ is USD-net-external-debt-to-GDP ratio of country $i$ in the year prior to event $t$. The sample is from January 1994 to December 2007 for a total of 112 events. The sample consists of the OECD currencies with flexible exchange rates. Standard errors are clustered at the event level and reported in parentheses. $* * *, * *$, and $*$ denote significance at the $1 \%, 5 \%$, and $10 \%$ levels, respectively.

\begin{tabular}{|c|c|c|c|c|}
\hline & $(1)$ & $(2)$ & (3) & $(4)$ \\
\hline$\mu_{t}$ & $\begin{array}{c}2.25 * * * \\
(0.67)\end{array}$ & $\begin{array}{c}2.27 * * * \\
(0.69)\end{array}$ & $\begin{array}{c}1.71 \\
(1.18)\end{array}$ & $\begin{array}{c}2.09 * * * \\
(0.59)\end{array}$ \\
\hline$U_{S D D e b t_{i, t-1}} \times \mu_{t}$ & $\begin{array}{c}6.70 * * * \\
(2.44)\end{array}$ & $\begin{array}{c}8.57 * * * \\
(2.87)\end{array}$ & $\begin{array}{l}7.64 * * \\
(2.93)\end{array}$ & $\begin{array}{c}8.04 * * \\
(3.12)\end{array}$ \\
\hline NetExport $_{i, t-1} \times \mu_{t}$ & $\begin{array}{l}-5.04 \\
(5.63)\end{array}$ & & & \\
\hline$U S D N e t$ Export $_{i, t-1} \times \mu_{t}$ & & $\begin{array}{c}2.82 \\
(2.60)\end{array}$ & & \\
\hline$U_{S D E x p r t} \operatorname{Exp}_{i, t} \times \mu_{t}$ & & & $\begin{array}{l}2.11 \\
(2.62)\end{array}$ & \\
\hline$U_{S D}$ Import $_{i, t-1} \times \mu_{t}$ & & & $\begin{array}{c}2.84 \\
(6.77)\end{array}$ & \\
\hline OilNetExport $_{i, t-1} \times \mu_{t}$ & & & & $\begin{array}{l}1.01 * * \\
(0.50)\end{array}$ \\
\hline Constant & $\begin{array}{l}-0.02 \\
(0.05)\end{array}$ & $\begin{array}{l}-0.02 \\
(0.06)\end{array}$ & $\begin{array}{c}0.02 \\
(0.07)\end{array}$ & $\begin{array}{l}-0.02 \\
(0.05)\end{array}$ \\
\hline Observations & 1,240 & 896 & 896 & 1,232 \\
\hline$R^{2}$ & 0.05 & 0.05 & 0.05 & 0.05 \\
\hline Number of countries & 18 & 14 & 14 & 18 \\
\hline
\end{tabular}


Table 5.11: Responses of Exchange Rates to U.S. Monetary Shocks (Macro Variables Robustness Checks)

This table shows the regression results of the following specification:

$$
\triangle s_{i, t}=\alpha+\beta_{\mu} \mu_{t}+\beta_{\text {Debt }}\left[\operatorname{Debt}_{i, t-1} \times \mu_{t}\right]+\gamma_{\text {Debt }} \operatorname{Debt}_{i, t-1}+\varepsilon_{i, t}
$$

where $\triangle s_{i, t}$ is the percentage change in the exchange rate in a one-day window bracketing the FOMC press release, positive $\triangle s_{i, t}$ is USD appreciation, $\mu_{t}$ is the measure of a US monetary policy shock based on fed funds futures, $U S D D e b t_{i, t-1}$ is USD-net-external-debt-to-GDP ratio of country $i$ in the year prior to event $t$. The sample is from January 1994 to December 2007 for a total of 112 events. The sample consists of the OECD currencies with flexible exchange rates. Standard errors are clustered at the event level and reported in parentheses. $* * *, * *$, and $*$ denote significance at the $1 \%, 5 \%$, and $10 \%$ levels, respectively.

\begin{tabular}{|c|c|c|c|c|}
\hline & (5) & (6) & (7) & (8) \\
\hline$\mu_{t}$ & $\begin{array}{l}1.97 * * \\
(0.68)\end{array}$ & $\begin{array}{c}2.11 * * * \\
(0.70)\end{array}$ & $\begin{array}{c}2.15 * * * \\
(0.65)\end{array}$ & $\begin{array}{c}2.06 * * \\
(0.75)\end{array}$ \\
\hline$U_{S D D e b t}{ }_{i, t-1} \times \mu_{t}$ & $\begin{array}{l}6.47 * * \\
(2.59)\end{array}$ & $\begin{array}{l}6.77 * * \\
(2.67)\end{array}$ & $\begin{array}{c}6.65 * * \\
(2.53)\end{array}$ & $\begin{array}{c}5.34 * * * \\
(1.75)\end{array}$ \\
\hline Domestic Debt $_{i, t-1} \times \mu_{t}$ & $\begin{array}{c}0.76 \\
(0.66)\end{array}$ & & & $\begin{array}{c}0.53 \\
(0.77)\end{array}$ \\
\hline Dom Gov Debt $_{i, t-1} \times \mu_{t}$ & & $\begin{array}{l}0.61 \\
(1.35)\end{array}$ & & \\
\hline $\operatorname{DomNonFCDebt}_{i, t-1} \times \mu_{t}$ & & & $\begin{array}{l}1.41 \\
(2.75)\end{array}$ & \\
\hline USDebt $\times$ Domestic Debt $\times \mu_{t}$ & & & & $\begin{array}{r}4.39 * * \\
(1.96)\end{array}$ \\
\hline Constant & $\begin{array}{c}0.07 \\
(0.06)\end{array}$ & $\begin{array}{c}0.06 \\
(0.07)\end{array}$ & $\begin{array}{c}0.06 \\
(0.06)\end{array}$ & $\begin{array}{c}0.07 \\
(0.06)\end{array}$ \\
\hline Observations & 1,200 & 1,200 & 1,200 & 1,200 \\
\hline$R^{2}$ & .06 & .06 & .06 & .06 \\
\hline Number of countries & 17 & 17 & 17 & 17 \\
\hline
\end{tabular}


Table 5.12: Responses of Exchange Rates to U.S. Monetary Shocks (by Sector)

This table shows the regression results of the following specification:

$$
\triangle s_{i, t}=\alpha+\beta_{\mu} \mu_{t}+\beta_{\text {SectorJDebt }}\left[\text { SectorJ Debt }_{i, t-1} \times \mu_{t}\right]+\gamma_{\text {SectorJDebt }} \text { SectorJDebt }_{i, t-1}+\varepsilon_{i, t}
$$

where $\triangle s_{i, t}$ is the percentage change in the exchange rate in a one-day window bracketing the FOMC press release, positive $\triangle s_{i, t}$ is USD appreciation, $\mu_{t}$ is the measure of a US monetary policy shock based on fed funds futures, SectorJ Debt $t_{i, t-1}$ is the net-external-debt-to-GDP ratio of sector $J$ in country $i$ in the year prior to event $t$. Three sectors exist: banking, public, and other sector. Public-sector debt is the sum of the government and central bank position. The sample period is January 1994-December 2007 for a total of 112 events. Standard errors are clustered at the event level and reported in parentheses. ***,**, and * denote significance at the $1 \%, 5 \%$, and $10 \%$ levels, respectively.

\begin{tabular}{|c|c|c|}
\hline & $(1)$ & (2) \\
\hline$M P S_{t}$ & $\begin{array}{c}1.61 * * \\
(0.65)\end{array}$ & $\begin{array}{c}1.61 * * \\
(0.70)\end{array}$ \\
\hline BankDebt $_{t-1} \times M P S_{t}$ & $\begin{array}{c}6.05 * * * \\
(1.77)\end{array}$ & $\begin{array}{c}5.80 * * * \\
(1.35)\end{array}$ \\
\hline OtherSDebt $_{t-1} \times M P S_{t}$ & $\begin{array}{c}4.98 * * \\
(2.34)\end{array}$ & $\begin{array}{l}4.86^{*} \\
(2.38)\end{array}$ \\
\hline Public Debt $_{t-1} \times M P S_{t}$ & $\begin{array}{l}-1.71 \\
(2.71)\end{array}$ & $\begin{array}{l}-1.76 \\
(2.84)\end{array}$ \\
\hline BankDebt $_{t-1}$ & $\begin{array}{l}-0.06 \\
(0.10)\end{array}$ & $\begin{array}{l}-0.28 \\
(0.17)\end{array}$ \\
\hline OtherSDebt $t_{t-1}$ & $\begin{array}{c}0.11 \\
(0.20)\end{array}$ & $\begin{array}{l}-0.24 \\
(0.23)\end{array}$ \\
\hline Public Debt $_{t-1}$ & $\begin{array}{l}-0.01 \\
(0.10)\end{array}$ & $\begin{array}{c}0.05 \\
(0.20)\end{array}$ \\
\hline Constant & $\begin{array}{l}-0.04 \\
(0.05)\end{array}$ & $\begin{array}{l}-0.01 \\
(0.06)\end{array}$ \\
\hline Observations & 1,200 & 478 \\
\hline$R^{2}$ & 0.06 & 0.17 \\
\hline Number of countries & 17 & 17 \\
\hline$|M P S|>2$ basis-point & No & Yes \\
\hline
\end{tabular}


Table 5.13: Responses of Exchange Rates to Monetary Shocks of BOJ and ECB

This table shows the regression results of the following specification applied to Bank of Japan (BOJ) and European Central Bank (ECB) monetary policy announcement days, separately:

$$
\triangle s_{i, t}=\alpha+\beta_{\mu} \mu_{t}+\beta_{\text {Debt }}\left[\operatorname{Debt}_{i, t-1} \times \mu_{t}\right]+\gamma_{D e b t} \text { Debt }_{i, t-1}+\varepsilon_{i, t}
$$

where $\triangle s_{i, t}$ is the percentage change in the exchange rate around central bank monetary policy announcement, positive $\triangle s_{i, t}$ is central bank's currency appreciation, $\mu_{t}$ is changes in two-year government bond yield, Japan government bond for BOJ events and Germany government for ECB events, CBDebt $t_{i, t-1}$ is net-external-debt denominated in central bank's currency, as a ratio to GDP, of country $i$ in the year prior to event $t$. NonCB denotes external debt denominated in currencies other than the central bank's. $\mu_{t}$ is normalized by one-standard deviation of one-day changes in bond yield on the event days. The sample is from January 1994 for BOJ, and from January 1999 for ECB, to December 2014 and excludes 2008. The sample consists of the 24 currencies with flexible exchange rates. Standard errors are clustered at the event level and reported in parentheses. $* * *, * *$, and $*$ denote significance at the $1 \%, 5 \%$, and $10 \%$ levels, respectively.

\begin{tabular}{lcccccc}
\hline & \multicolumn{3}{c}{ BOJ } & \multicolumn{3}{c}{ ECB } \\
\cline { 2 - 7 } & $(1)$ & $(2)$ & $(3)$ & $(5)$ & $(6)$ & $(7)$ \\
\hline$\mu_{t}$ & $0.12^{*}$ & 0.07 & 0.11 & 0.05 & 0.01 & 0.05 \\
& $(0.06)$ & $(0.09)$ & $(0.08)$ & $(0.04)$ & $(0.05)$ & $(0.04)$ \\
CBDebt ${ }_{i, t-1} \times \mu_{t}$ & $0.64^{*}$ & $1.73^{* * *}$ & $1.00^{* * *}$ & $0.04^{* *}$ & 0.01 & $0.04^{* *}$ \\
& $(0.36)$ & $(0.41)$ & $(0.31)$ & $(0.02)$ & $(0.03)$ & $(0.02)$ \\
NonCBDebt $t_{i, t-1} \times \mu_{t}$ & -0.01 & -0.01 & -0.05 & -0.05 & 0.12 & -0.06 \\
& $(0.04)$ & $(0.05)$ & $(0.04)$ & $(0.07)$ & $(0.11)$ & $(0.07)$ \\
CBDebt $t_{i, t-1}$ & $0.94^{*}$ & 1.03 & $2.34 * *$ & 0.01 & 0.01 & 0.02 \\
& $(0.51)$ & $(0.70)$ & $(1.06)$ & $(0.02)$ & $(0.03)$ & $(0.02)$ \\
NonCBDebt & 0.01 & 0.00 & -0.18 & -0.09 & -0.03 & -0.15 \\
& $(0.03)$ & $(0.03)$ & $(0.11)$ & $(0.07)$ & $(0.10)$ & $(0.09)$ \\
Constant & -0.06 & -0.06 & -0.14 & 0.00 & -0.07 & 0.01 \\
& $(0.05)$ & $(0.07)$ & $(0.15)$ & $(0.03)$ & $(0.04)$ & $(0.04)$ \\
Observations & & & & & & \\
$R^{2}$ & 2,526 & 2,526 & 316 & 1,776 & 1,776 & 1,158 \\
Number of countries & 18 & 18 & 18 & 17 & 17 & 17 \\
Event window & 1 -day & 2 -day & 1 -day & 1 -day & 2 -day & 1 -day \\
$|\triangle r|>2$ basis-point & No & No & Yes & No & No & Yes \\
\hline
\end{tabular}




\section{Table 5.14: Responses of External Debt Issuance to U.S. Monetary Shocks}

This table reports the OLS estimates of $\left\{\beta_{k}, \beta_{k, \text { Debt }}\right\}$ of specification 3.2:

$$
\begin{aligned}
\triangle \text { Debt }_{i, t} & =\sum_{k=0}^{T} \beta_{k} \mu_{t-k}+\sum_{k=0}^{T} \beta_{k, \text { Debt }}\left[\text { Debt }_{i, t-k-1} \times \mu_{t-k}\right]+\sum_{k=0}^{T} \gamma_{k, \text { Debt }}\left[\text { Debt }_{i, t-k-1}\right] \\
& + \text { control }_{i, t-T}+\varepsilon_{i, t}
\end{aligned}
$$

where $\triangle D e b t_{i, t}$ is USD international debt issuance of country $i$ at quarter $t$ divided by GDP, $\mu_{t}$ is US monetary policy shocks in quarter $t$, positive $\mu_{t}$ is an unexpected fed-funds-rate increase, and $D e b t_{i, t-k-1}$ is country $i$ 's USD-net-external-debt-to-GDP ratio at the end of quarter $t$ - $k-1$. The control variables are lagged dependent variables from lag 6 to lag 9, country fixed effects, quarter fixed effects, and time trend. The sample period is 1994-2007. Standard errors are heteroscedasticity and six-lag serial-correlation consistent and reported in parentheses. $* * *, * *$, and $*$ denote significance at the $1 \%, 5 \%$, and $10 \%$ levels, respectively.

\begin{tabular}{cccccccc}
\hline & $\operatorname{lag} 0$ & $\operatorname{lag} 1$ & $\operatorname{lag} 2$ & $\operatorname{lag} 3$ & $\operatorname{lag} 4$ & $\operatorname{lag} 5$ & Cumulative \\
\hline \multirow{3}{*}{$\beta_{k}$} & -0.23 & $0.74 * *$ & $0.40 *$ & 0.18 & -0.07 & -0.42 & .62 \\
& $(0.28)$ & $(0.30)$ & $(0.22)$ & $(0.25)$ & $(0.38)$ & $(0.34)$ & $(1.03)$ \\
$\beta_{\text {Debt }, k}$ & -0.92 & $-2.44 * *$ & $-2.13 * * *$ & $-1.80 * * *$ & -1.10 & 0.73 & $-7.65 * * *$ \\
& $(0.76)$ & $(0.98)$ & $(0.65)$ & $(0.63)$ & $(0.90)$ & $(1.67)$ & $(1.70)$ \\
\hline
\end{tabular}


Table 5.15: Responses of External Debt Issuance to U.S. Monetary Shocks (with Non-USD External Debt as Regressors)

This table reports the OLS estimates of $\left\{\beta_{k}, \beta_{k, \text { Debt }}\right\}$ of specification 3.2:

$$
\begin{aligned}
\triangle \text { Debt }_{i, t} & =\sum_{k=0}^{T} \beta_{k} \mu_{t-k}+\sum_{k=0}^{T} \beta_{k, \text { Debt }}\left[\text { Debt }_{i, t-k-1} \times \mu_{t-k}\right]++\sum_{k=0}^{T} \gamma_{k, d e b t}\left[\text { Debt }_{i, t-k-1}\right] \\
& + \text { control }_{i, t-T}+\varepsilon_{i, t}
\end{aligned}
$$

where $\triangle D e b t_{i, t}$ is USD international debt issuance of country $i$ at quarter $t$ divided by GDP, $\mu_{t}$ is US monetary policy shocks in quarter $t$, positive $\mu_{t}$ is an unexpected rate increase, and $U S D D e b t_{i, t-k-1}$ is country $i$ 's USD-net-external-debt-to-GDP ratio at the end of quarter $t-k-1$, and NonUSDDebt $t_{i, t-k-1}$ is country $i$ 's non-USD-net-external-debt-to-GDP ratio. The control variables are lagged dependent variables from lag 6 to lag 9, country fixed effects, quarter fixed effects, and time trend. The sample period is 1994-2007. Standard errors are heteroscedasticity and six-lag serial-correlation consistent and reported in parentheses. ***, $* *$, and $*$ denote significance at the $1 \%, 5 \%$, and $10 \%$ levels, respectively.

\begin{tabular}{cccccccc}
\hline & lag 0 & lag 1 & lag 2 & lag 3 & lag 4 & lag 5 & Cumulative \\
\hline \multirow{3}{*}{$\beta_{k}$} & -0.35 & $0.57^{*}$ & 0.35 & 0.38 & -0.11 & -0.30 & .54 \\
& $(0.33)$ & $(0.31)$ & $(0.33)$ & $(0.32)$ & $(0.52)$ & $(0.32)$ & $(1.39)$ \\
$\beta_{U S D D e b t, k}$ & -0.77 & $-2.23 * * *$ & $-2.37 * * *$ & $-1.98^{* * *}$ & -1.54 & 0.69 & $-8.20^{* * *}$ \\
& $(0.73)$ & $(0.78)$ & $(0.68)$ & $(0.60)$ & $(0.99)$ & $(1.45)$ & $(1.82)$ \\
$\beta_{\text {NonUSDDebt }, k}$ & 0.55 & 0.48 & -0.23 & -0.35 & -0.56 & -0.42 & -.53 \\
& $(0.63)$ & $(0.76)$ & $(0.95)$ & $(0.90)$ & $(0.86)$ & $(1.17)$ & $(3.04)$ \\
& & & & & & & \\
\hline
\end{tabular}


Table 5.16: Responses of International Debt Issuance to U.S. Monetary Shocks (by Currency of Issuance)

This table reports the OLS estimates of $\left\{\beta_{k}, \beta_{k, \text { Debt }}\right\}$ of specification 3.2:

$$
\begin{aligned}
\triangle \text { NonUSDDebt }_{i, t} & =\sum_{k=0}^{T} \beta_{k} \mu_{t-k}+\sum_{k=0}^{T} \beta_{k, \text { Debt }}\left[\text { Debt }_{i, t-k-1} \times \mu_{t-k}\right]++\sum_{k=0}^{T} \gamma_{k, \text { debt }}\left[\text { Debt }_{i, t-k-1}\right] \\
& + \text { control }_{i, t-T}+\varepsilon_{i, t}
\end{aligned}
$$

where $\triangle N o n U S D D^{2} b t_{i, t}$ is international-debt issuance in non-USD currencies of country $i$ at quarter $t$ divided by GDP, $\mu_{t}$ is US monetary policy shocks in quarter $t$, positive $\mu_{t}$ is an unexpected fed-funds-rate increase, and $D e b t_{i, t-k-1}$ is country $i$ 's USD-net-external-debt-to-GDP ratio at the end of quarter $t-k-1$. The control variables are lagged dependent variables from lag 6 to lag 9, country fixed effects, quarter fixed effects, and time trend. The sample period is 1994-2007. Standard errors are heteroscedasticity and six-lag serial-correlation consistent and reported in parentheses. $* * *, * *$, and $*$ denote significance at the $1 \%, 5 \%$, and $10 \%$ levels, respectively.

\begin{tabular}{cccccccc}
\hline Non USD & $\operatorname{lag} 0$ & $\operatorname{lag} 1$ & $\operatorname{lag} 2$ & $\operatorname{lag} 3$ & $\operatorname{lag} 4$ & $\operatorname{lag} 5$ & Cumulative \\
\hline \multirow{3}{*}{$\beta_{k}$} & 0.32 & 0.42 & 0.17 & $0.67^{* *}$ & 0.15 & -0.13 & $1.60^{*}$ \\
& $(0.30)$ & $(0.34)$ & $(0.16)$ & $(0.26)$ & $(0.23)$ & $(0.24)$ & $(.90)$ \\
$\beta_{U S D D e b t, k} k$ & -0.48 & $-1.06^{* *}$ & $-2.40^{* * *}$ & $-2.23^{* *}$ & $-1.62^{* *}$ & -1.00 & $-8.79 * * *$ \\
& $(0.60)$ & $(0.39)$ & $(0.58)$ & $(0.80)$ & $(0.67)$ & $(0.71)$ & $(2.87)$ \\
& & & & & & & \\
\hline
\end{tabular}


Table 5.17: Responses of International Debt Issuance to U.S. Monetary Shocks (by Sector of Issuer)

This table reports the OLS estimates of $\left\{\beta_{k}, \beta_{k, \text { Debt }}\right\}$ of specification 3.2:

$$
\begin{aligned}
\triangle \text { SectorJ Debt }_{i, t} & =\sum_{k=0}^{T} \beta_{k} \mu_{t-k}+\sum_{k=0}^{T} \beta_{k, \text { Debt }}\left[\text { Debt }_{i, t-k-1} \times \mu_{t-k}\right]+\sum_{k=0}^{T} \gamma_{k, \text { debt }}\left[\text { Debt }_{i, t-k-1}\right] \\
& + \text { control }_{i, t-T}+\varepsilon_{i, t}
\end{aligned}
$$

where $\triangle$ SectorJ Debt $t_{i, t}$ is USD international debt issuance of sector $J$ in country $i$ at quarter $t$ divided by GDP, $\mu_{t}$ is US monetary policy shocks in quarter $t$, positive $\mu_{t}$ is an unexpected fed-funds-rate increase, and Debt $_{i, t-k-1}$ is country $i$ 's USD-net-external-debt-to-GDP ratio at the end of quarter $t-k-1$. Country-level debt issuance is decomposed into two sectors, banking and non-banking. The control variables are lagged dependent variables from lag 6 to lag 9, country fixed effects, quarter fixed effects, and time trend. The sample period is 1994-2007. Standard errors are heteroscedasticity and six-lag serial-correlation consistent and reported in parentheses. $* * *, * *$, and $*$ denote significance at the $1 \%, 5 \%$, and $10 \%$ levels, respectively.

\begin{tabular}{cccccccc}
\hline Banking & lag 0 & lag 1 & lag 2 & lag 3 & lag 4 & lag 5 & Cumulative \\
\hline \multirow{2}{*}{$\beta_{k}$} & 0.07 & 0.38 & 0.36 & 0.06 & -0.03 & -0.30 & .53 \\
& $(0.18)$ & $(0.24)$ & $(0.21)$ & $(0.15)$ & $(0.26)$ & $(0.29)$ & $(.82)$ \\
$\beta_{U S D D e b t, k}$ & $-1.10^{* *}$ & $-1.95^{*}$ & $-1.21^{*}$ & $-0.75^{*}$ & -0.63 & 0.58 & $-5.07^{* * *}$ \\
& $(0.39)$ & $(0.97)$ & $(0.69)$ & $(0.37)$ & $(0.46)$ & $(1.31)$ & $(1.58)$ \\
& & & & & & & \\
\hline Non-Banking & lag 0 & lag 1 & lag 2 & lag 3 & lag 4 & lag 5 & Cumulative \\
\hline \multirow{2}{*}{$\beta_{k}$} & -0.30 & $0.35^{* * *}$ & 0.04 & 0.10 & -0.06 & -0.12 & .02 \\
& $(0.21)$ & $(0.09)$ & $(0.12)$ & $(0.13)$ & $(0.17)$ & $(0.12)$ & $(.36)$ \\
$\beta_{U S D D e b t, k}$ & 0.25 & -0.47 & $-0.96^{* *}$ & $-1.02^{* *}$ & -0.35 & -0.08 & $-2.63^{*}$ \\
& $(0.78)$ & $(0.35)$ & $(0.36)$ & $(0.42)$ & $(0.74)$ & $(0.41)$ & $(1.50)$ \\
& & & & & & & \\
\hline
\end{tabular}


Table 5.18: Summary Statistics of Exchange Rate Changes around Rare Disasters

This table shows the summary statistics of the exchange rate changes in three-business-day window $\triangle s(3 D)$, from $t-1$ to $t+2$ closing price, and 20-business-day window $\triangle s(1 M)$, from $t-1$ to $t+19$, bracketing the raredisaster events of each portfolio. $U S D D e b t_{-1}$ and $D e b t_{-1}$ are the USD-net-external-debt-to-GDP and netexternal-debt-to-GDP ratios in all currencies in the year prior to an event. Portfolios 1 and 4 consist of currencies with the lowest and highest $U S D D e b t_{-1}$, respectively. The rare-disaster events are the collapse of Long Term Capital Management in September 1998, the terrorist attack on September 11 2001, and the bankruptcy filing of Lehman Brothers on September 15, 2008. All values are in percent.

\begin{tabular}{lcccccc}
\hline \hline \multirow{2}{*}{ LTCM } & \multicolumn{7}{c}{ Portfolio } \\
\cline { 2 - 7 }$\triangle S(1 M)$ & 1 & 2 & 3 & 4 & Average & HML \\
\hline USD ebt $_{-1}$ & -2.92 & -1.13 & -0.39 & 3.77 & -0.17 & 6.69 \\
Debt -1 & -0.31 & 0.13 & 0.19 & 0.28 & 0.07 & 0.58 \\
& -0.10 & 0.27 & 0.32 & 0.43 & 0.22 & 0.58 \\
& \multicolumn{7}{c}{ Portfolio } \\
9/11 Terrorist Attack & 1 & 2 & 3 & 4 & Average & HML \\
\hline$\triangle S(2 D)$ & -1.97 & -0.07 & 2.20 & 3.03 & 0.80 & 5.00 \\
$\triangle S(1 M)$ & -0.97 & 0.89 & 3.49 & 7.38 & 2.70 & 8.35 \\
$U S D D e b t_{-1}$ & -0.44 & 0.13 & 0.21 & 0.49 & 0.10 & 0.94 \\
Debt_1 & -0.10 & 0.32 & 0.34 & 0.71 & 0.30 & 0.88
\end{tabular}

\begin{tabular}{lcccccc}
\hline & \multicolumn{7}{c}{ Portfolio } \\
\cline { 2 - 7 } Lehman Brothers & 1 & 2 & 3 & 4 & Average & HML \\
\hline$\triangle S(2 D)$ & 0.10 & 0.74 & 1.53 & 2.16 & 1.13 & 2.06 \\
$\triangle s(1 M)$ & 3.44 & 8.14 & 10.14 & 11.73 & 8.36 & 8.30 \\
$U S D D e b t_{-1}$ & -0.39 & 0.10 & 0.14 & 0.39 & 0.06 & 0.78 \\
$D e b t_{-1}$ & -0.09 & -0.11 & 0.21 & 0.84 & 0.21 & 0.93
\end{tabular}


Table 5.19: USDebt and the Cross-Sectional Variation in Currency Excess Returns

This table reports the estimates of $r x_{i, t, t+k}=\alpha_{i}+\beta_{D e b t} U S D e b t_{i, t}+\beta_{F} F_{i, t}+\varepsilon_{i, t}$, where $r x_{i, t, t+k}$ is $k$-month excess returns of currency $i$, expressed in dollars, $k$ is $3, U S D e b t_{i, t}$ is dollar debt of country $i$ at the end of the previous year of month $t, F C N o n U S D D e b t_{i, t}$ is foreign-currency-non-USD denominated debt, DCDebt $t_{i, t}$ is domestic-currency denominated debt, and Equit $y_{i, t}$ is net external equity. The sample consists of the OECD currencies with flexible exchange rates. The sample period is from January 1994 to December 2014. Standard errors are clustered at the quarter and country levels based on Cameron, Gelbach, and Miller (2006), and reported in parentheses. ***, **, and * denote significance at the $1 \%, 5 \%$, and $10 \%$ levels, respectively.

\begin{tabular}{|c|c|c|c|c|c|c|c|}
\hline Dependent variable & & & $r x$ &,$t+3(3 \mathrm{mor}$ & $t h)$ & & \\
\hline$U S D e b t_{i, t}$ & $\begin{array}{c}0.45^{* *} \\
(0.17)\end{array}$ & $\begin{array}{c}0.54 * * \\
(0.20)\end{array}$ & $\begin{array}{c}0.59 * * \\
(0.25)\end{array}$ & $\begin{array}{c}0.62 * * \\
(0.27)\end{array}$ & $\begin{array}{c}0.40 * * \\
(0.16)\end{array}$ & $\begin{array}{l}0.33 * \\
(0.19)\end{array}$ & $\begin{array}{c}0.51 * * \\
(0.21)\end{array}$ \\
\hline FCNonUSDDebt $t_{i, t}$ & & $\begin{array}{c}0.25 \\
(0.15)\end{array}$ & & & & & \\
\hline$D C D e b t_{i, t}$ & & $\begin{array}{l}-0.03 \\
(0.14)\end{array}$ & & & & & \\
\hline Equity $_{i, t}$ & & $\begin{array}{l}-0.02 \\
(0.09)\end{array}$ & & & & & \\
\hline Export $_{i, t}$ & & & $\begin{array}{l}-0.10 \\
(0.14)\end{array}$ & & & & \\
\hline Import $_{i, t}$ & & & & $\begin{array}{l}-0.12 \\
(0.15)\end{array}$ & & & \\
\hline Size $_{i, t}$ & & & & & $\begin{array}{c}-0.07 * * * \\
(0.02)\end{array}$ & & \\
\hline TradeCentrality $y_{i, t}$ & & & & & & $\begin{array}{l}-0.38 \\
(0.27)\end{array}$ & \\
\hline $\operatorname{OilNX} X_{i, t}$ & & & & & & & $\begin{array}{c}0.03 \\
(0.02)\end{array}$ \\
\hline Constant & $\begin{array}{c}0.05 * * * \\
(0.01)\end{array}$ & $\begin{array}{c}0.03 \\
(0.02)\end{array}$ & $\begin{array}{l}0.11 * \\
(0.05)\end{array}$ & $\begin{array}{c}0.11 * * \\
(0.05)\end{array}$ & $\begin{array}{c}0.08 * * * \\
(0.01)\end{array}$ & $\begin{array}{c}0.51 \\
(0.32)\end{array}$ & $\begin{array}{c}0.05 * * * \\
(0.01)\end{array}$ \\
\hline Observations & 2445 & 2445 & 2445 & 2445 & 2445 & 2445 & 2445 \\
\hline$R^{2}$ & 0.36 & 0.35 & 0.35 & 0.35 & 0.36 & 0.35 & 0.36 \\
\hline No. of Countries & 17 & 17 & 17 & 17 & 17 & 17 & 17 \\
\hline
\end{tabular}




\section{Table 5.20: Summary Statistics of Excess Returns of USDebt Portfolios}

This table reports, for each portfolio, the average one-month log excess return $r x_{t+1}$ and one-month nominal interest rate differentials implied by log forward premia, $f_{t}-s_{t}$. Log excess returns are computed as $r x_{t+1}=f_{t}-s_{t}-\triangle s_{t+1}$. All moments are annualized and reported in percentage points. The portfolios are constructed by sorting currencies into four groups every beginning of each year based on their USD-netexternal-debt-to-GDP in the previous year. Currencies in sample are the currencies of OECD countries with flexible exchange regime. The sample period is from January 1994 to December 2014 for 252 observations.

\begin{tabular}{lcccccc}
\hline & Lowest & \multicolumn{5}{c}{ Highest } \\
& USDebt & Port 2 & Port 3 & USDebt & Average & USDebt-HML \\
\hline$r x_{t+1}$ & -0.18 & 1.40 & 3.05 & 5.28 & 2.39 & 5.46 \\
$f p_{t}$ & -0.15 & 1.74 & 2.66 & 5.76 & 2.50 & 5.91 \\
$\triangle s_{t+1}$ & 0.03 & 0.34 & -0.39 & 0.48 & 0.12 & 0.45 \\
Standard deviation & 6.43 & 6.69 & 6.61 & 8.08 & 6.02 & 6.99 \\
Sharpe ratio & -0.03 & 0.21 & 0.46 & 0.65 & 0.40 & 0.78 \\
USDebt $t$ & -0.07 & 0.08 & 0.15 & 0.26 & 0.11 & 0.32 \\
& & & & & & \\
\hline
\end{tabular}


Table 5.21: Summary Statistics of Two-day Excess Returns of USDebt Portfolios around the Scheduled FOMC Announcements

This table reports, for each portfolio, the average two-day excess return $r x_{t+1}$ in 48 hours, from day $t-2$ closing price to day $t$ closing price, bracketing the scheduled FOMC press releases. The two-day excess returns are computed as $r x_{t+1}=\left(f_{t}-s_{t}\right) \times 2 / 30-\triangle s_{t+1}$ where $\left(f_{t}-s_{t}\right) \times 2 / 30$ is one-month interest rate differentials accrued for two-day and $\triangle s_{t+1}$ is USD appreciation in the two-day window. All moments are annualized based on 8 events per year and reported in percentage points. The portfolios are constructed by sorting currencies into four groups based on their USD-net-external-debt-to-GDP before each event. Currencies in sample are the currencies of OECD countries with flexible exchange regime. The sample period is from January 1994 to December 2007 for a total of 112 events.

\begin{tabular}{lcccccc}
\hline & Lowest & \multicolumn{5}{c}{ Highest } \\
& USDebt & Port 2 & Port 3 & USDebt & Average & USDebt-HML \\
\hline$r x_{t+1}$ & 0.33 & 0.59 & 0.74 & 1.45 & 0.82 & 1.04 \\
$f p_{t}$ & -0.04 & 0.08 & 0.12 & 0.11 & 0.11 & 0.07 \\
$\triangle s$ & -0.37 & -0.50 & -0.62 & -1.34 & -0.71 & -0.97 \\
Standard deviation & 1.99 & 1.97 & 1.86 & 1.98 & 1.66 & 1.92 \\
Sharpe ratio & 0.17 & 0.30 & 0.40 & 0.73 & 0.49 & 0.54 \\
USDebt $t$ & -0.08 & 0.08 & 0.14 & 0.22 & 0.09 & 0.30 \\
& & & & & & \\
\hline
\end{tabular}


Table 5.22: Summary Statistics of Two-day Excess Returns of Different USDebt, Country Size, and Trade Network Centrality Portfolios around the Scheduled FOMC Press Release

This table reports, for each portfolio, the average two-day excess return $r x_{t+1}$ in 48 hours, from day $t-2$ closing price to day $t$ closing price, bracketing the scheduled FOMC press releases. The two-day excess returns are computed as $r x_{t+1}=\left(f_{t}-s_{t}\right) \times 2 / 30-\triangle s_{t+1}$ where $\left(f_{t}-s_{t}\right) \times 2 / 30$ is one-month interest rate differentials accrued for two-day and $\triangle s_{t+1}$ is USD appreciation in the two-day window. All moments are annualized based on 8 events per year and reported in percentage points. The portfolios are constructed by sorting currencies into four groups based on their USD-net-external-debt-to-GDP ratios and GDP share, or USD-net-external-debt-to-GDP ratios and trade network centrality (Richmond 2017) before each event. Currencies in sample are the currencies of OECD countries with flexible exchange regime. The sample period is from January 1994 to December 2007 for a total of 112 events.

(a) Double Sort on USDebt and Country Size

\begin{tabular}{clcc}
\hline & & Low USDebt & High USDebt \\
\hline \multirow{2}{*}{ Big Countries } & Two-day $r x$ & 0.32 & 1.58 \\
& Standard Deviation & 1.89 & 1.59 \\
& Sharpe Ratio & 0.17 & 0.99 \\
Small Countries & & \\
& & 0.62 & 0.79 \\
& Two-day $r x$ & 2.11 & 2.35 \\
& Standard Deviation & 0.29 & 0.34 \\
& Sharpe Ratio & & \\
\hline
\end{tabular}

(b) Double Sort on USDebt and Centrality

\begin{tabular}{clcc}
\hline & & Low USD Debt & High USD Debt \\
\hline Central Countries & Two-day $r x$ & 0.57 & 0.87 \\
& Standard Deviation & 1.78 & 2.23 \\
& Sharpe Ratio & 0.32 & 0.39 \\
Peripheral Countries & & \\
& Two-day $r x$ & 0.32 & 1.53 \\
& Standard Deviation & 2.06 & 1.90 \\
& Sharpe Ratio & 0.16 & 0.81 \\
\hline
\end{tabular}




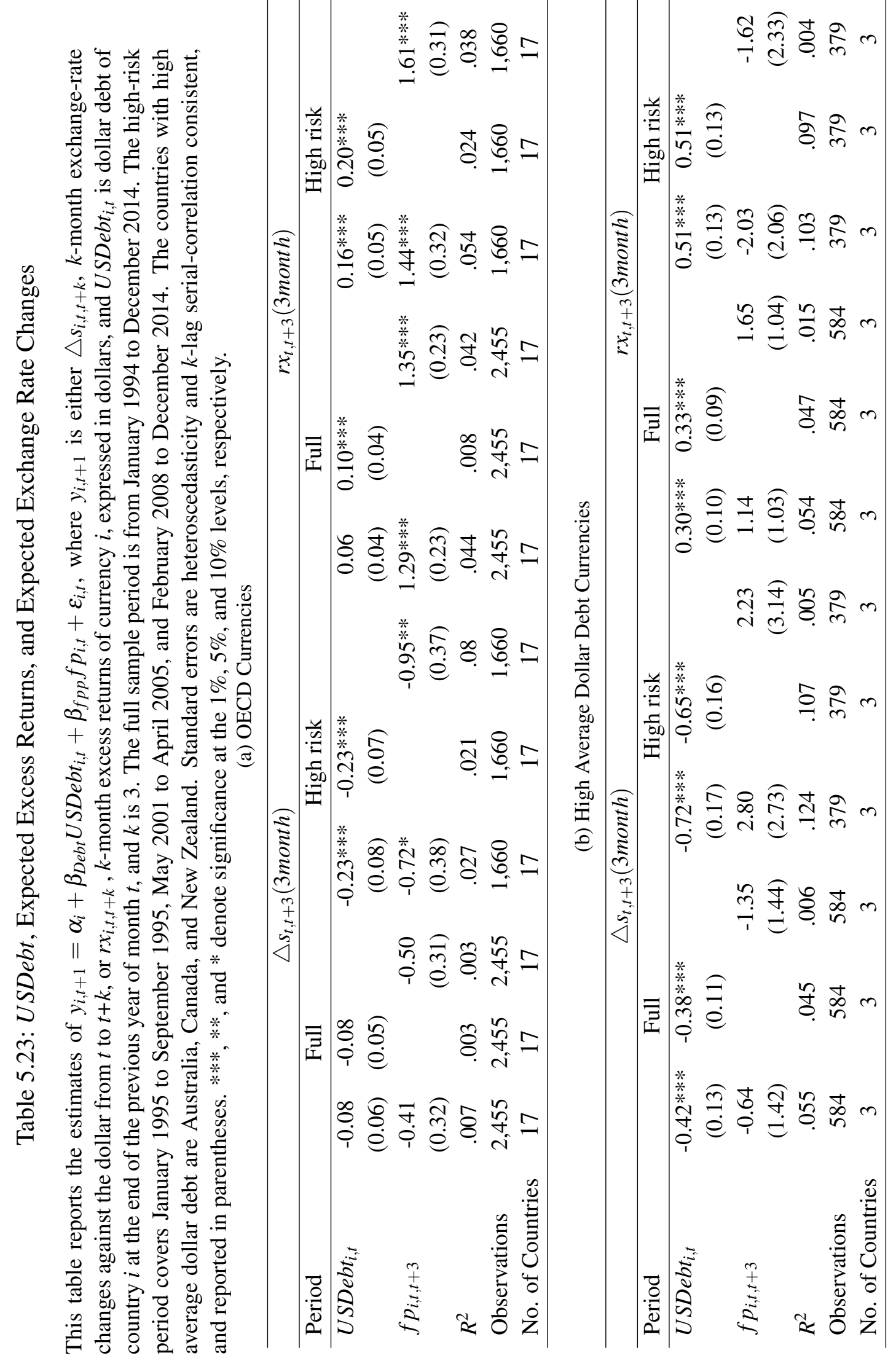


Table 5.24: Summary Statistics of Exchange Rate Changes around the U.S. Large Scale Asset Purchases (LSAP) Announcements

This table reports the average two-day and one-week exchange rate changes around LSAP announcements of countries with the lowest to the highest USD net-external debt-to-GDP ratio. The sample does not include Iceland. Countries are allocated to groups based on their debt position before the announcements. The dates of Quantitative Easing (QE) I announcements are November 25, 2008, December 1, 2008, December 16, 2008, January 28, 2009, and March 18, 2009. The dates of QE II announcements are August 10, 2010, September 21, 2010, and November 3, 2010.

\begin{tabular}{cccc}
\hline & \multicolumn{3}{c}{ QE 1 } \\
\cline { 2 - 4 } Portfolio & Lowest Debt & \multicolumn{2}{c}{ Highest Debt } \\
\hline Two-day $\triangle s$ & -1.13 & -0.58 & -0.95 \\
& $(2.62)$ & $(1.85)$ & $(2.81)$ \\
One-week $\triangle s$ & -0.04 & -0.33 & -0.40 \\
& $(2.31)$ & $(1.78)$ & $(2.71)$ \\
USD Debt & -0.06 & 0.10 & 0.17 \\
& & & \\
\hline & & QE 2 & \\
\cline { 2 - 4 } Portfolio & Lowest Debt & & Highest Debt \\
Two-day $\triangle s$ & -0.12 & -0.20 & -0.22 \\
One-week $\triangle s$ & $(1.29)$ & $(0.86)$ & $(1.12)$ \\
& 0.01 & -0.26 & -0.39 \\
USD Debt & $(1.68)$ & $(1.18)$ & $(0.98)$ \\
& -0.03 & 0.10 & 0.19 \\
& & & \\
& & &
\end{tabular}




\section{FIGURES}

Figure 5.1: Exchange-rate Sensitivities to U.S. Monetary Policy Shocks versus Alternative Measures of Dollar-Debt Level
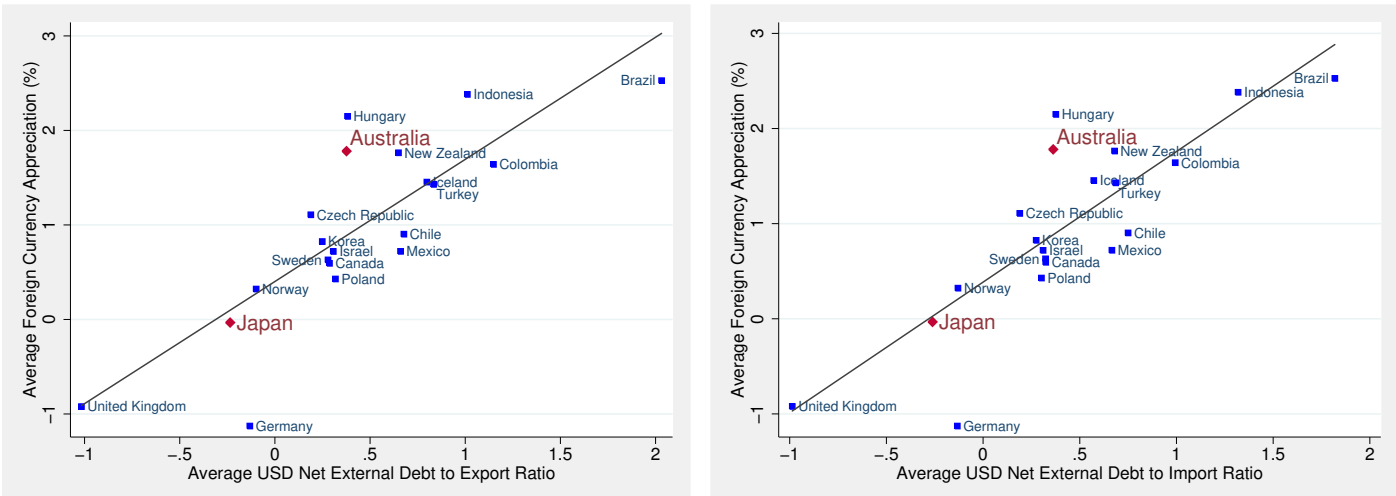

Figure 5.2: The Marginal Impulse Response of USD External Debt Issuance of Countries with USDebt of $25 \%$

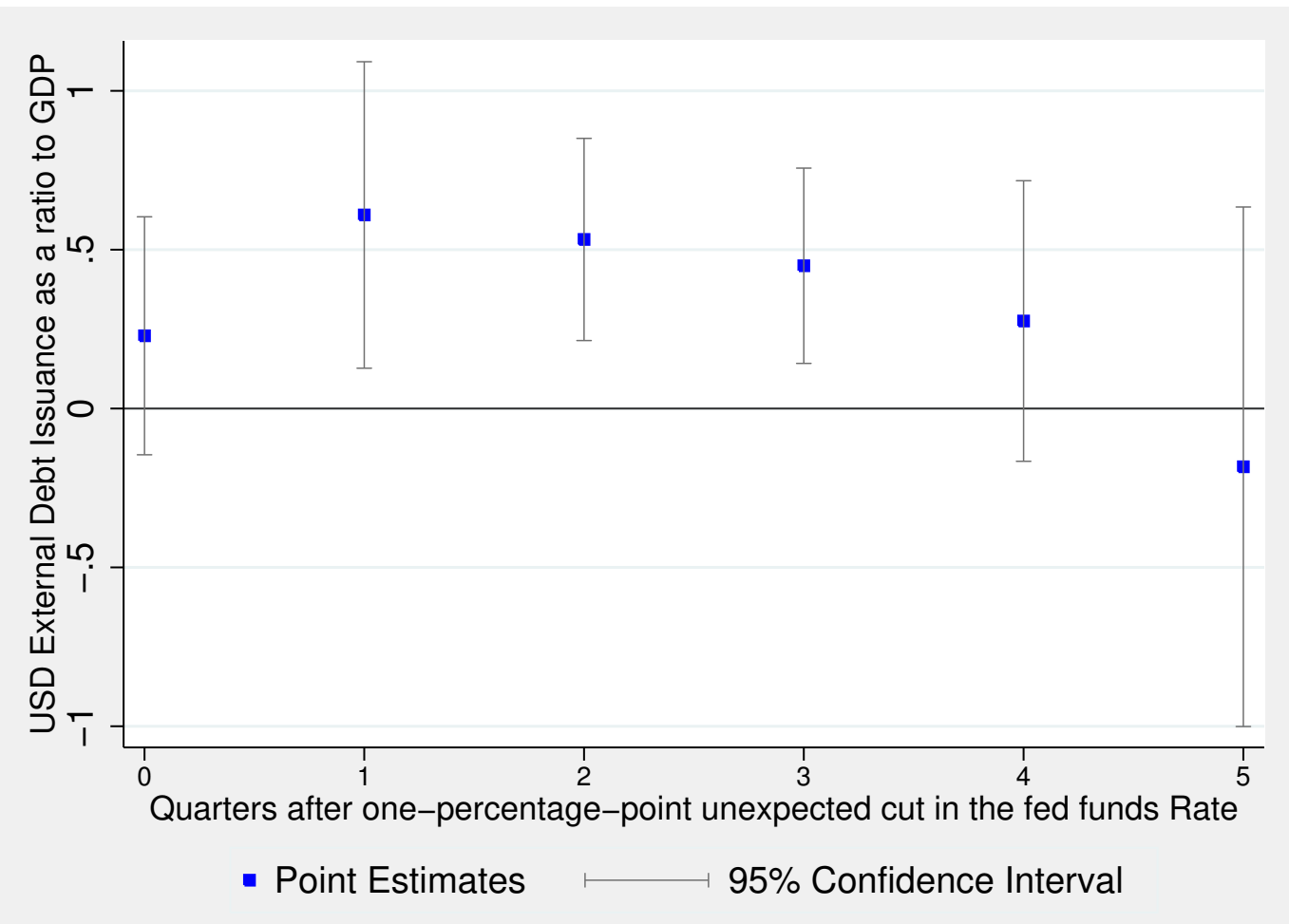


Figure 5.3: Exchange-Rate Sensitivity to Rare Disasters vs. USDebt

(a) Two-day Window
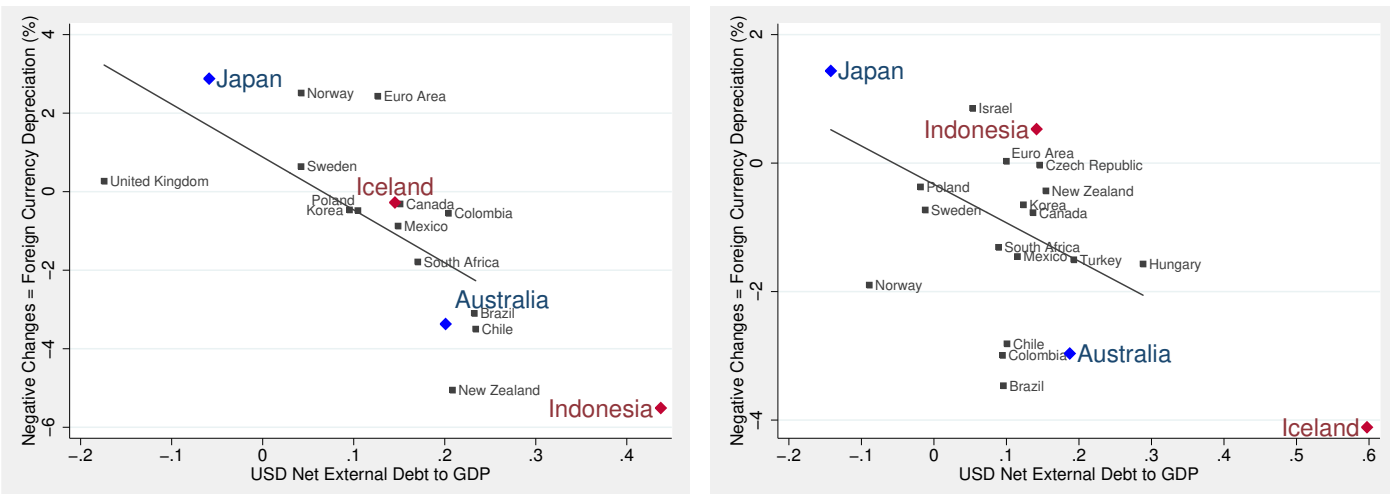

(b) One-month Window
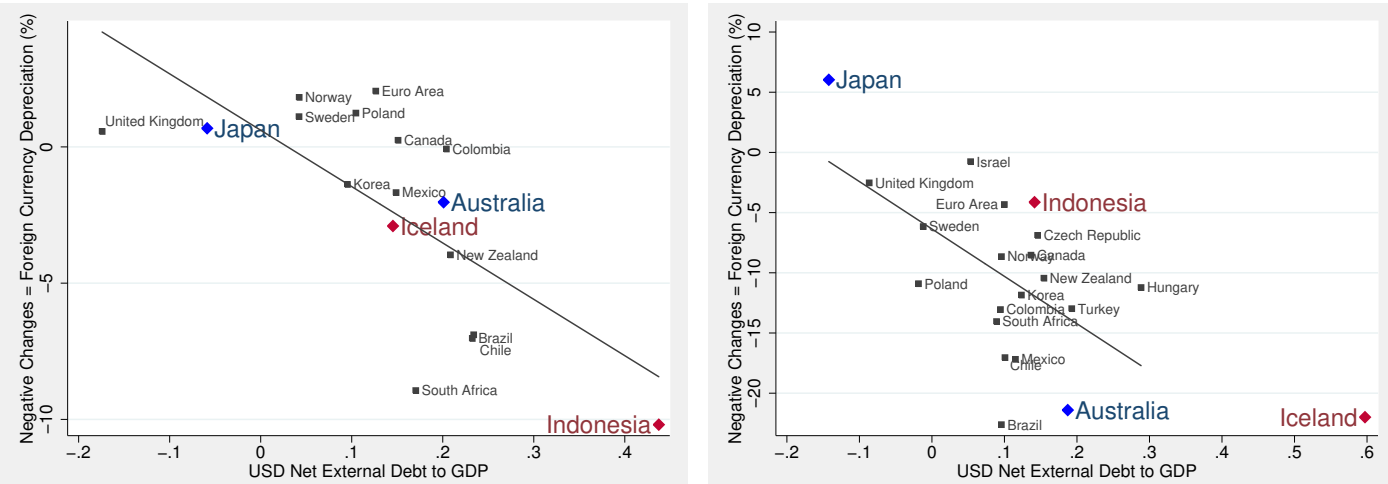

Panel (a) left figure plots the changes in exchange rates from the closing rate on Monday, September 10, 2001, to the closing rate on Monday, September 17, 2001, against foreign countries' exante USD net-external-debt-to-GDP ratios (USDebt). The U.S. financial markets are closed from September 11, 2011, and reopen in September 17, 2001. Panel (a) right figure plots the changes in exchange rates from closing rate on Friday, September 12, 2008 to the closing rate on Tuesday, September 16, 2008, against USDebt. Lehman Brothers filed for Chapter 11 bankruptcy protection on Monday, September 15, 2008. 
Figure 5.4: Exchange-Rate Sensitivity to Rare Disasters vs. USDebt

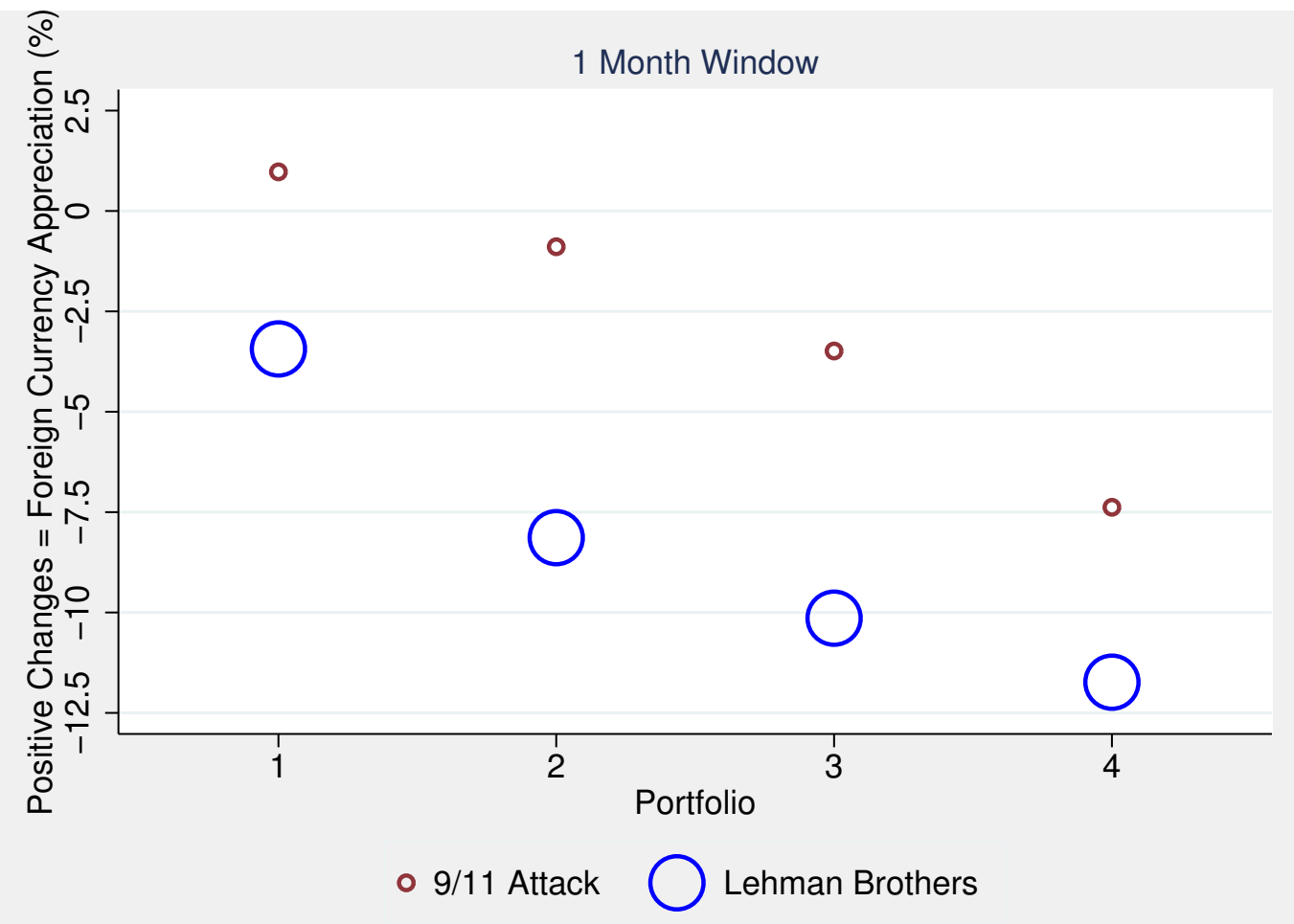


Figure 5.5: One-month Forward Premia versus USDebt
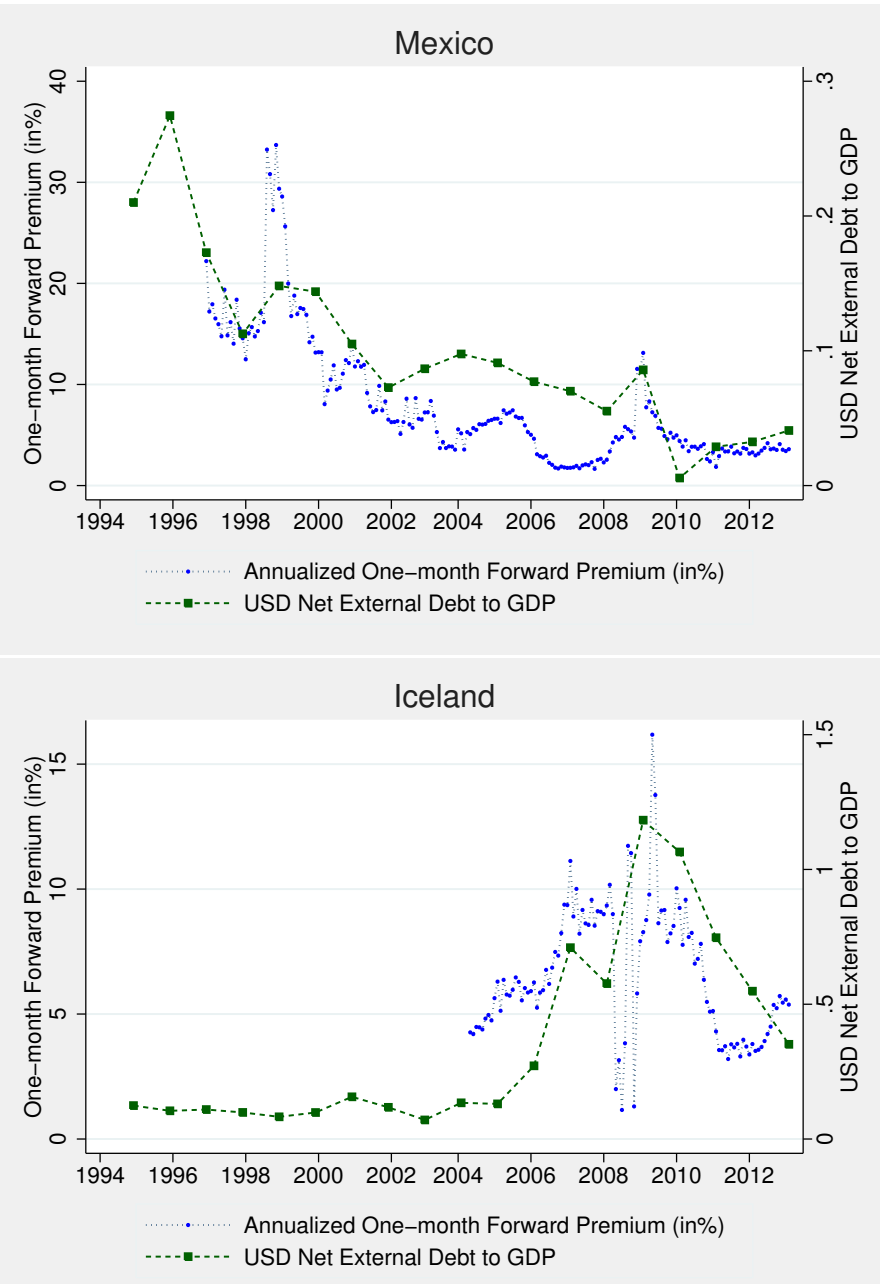
Figure 5.6: Time Series of Foreign Central Banks' Policy Rates of Low and High-USDebt countries during the U.S. Quantitative Easing (QE) I and II

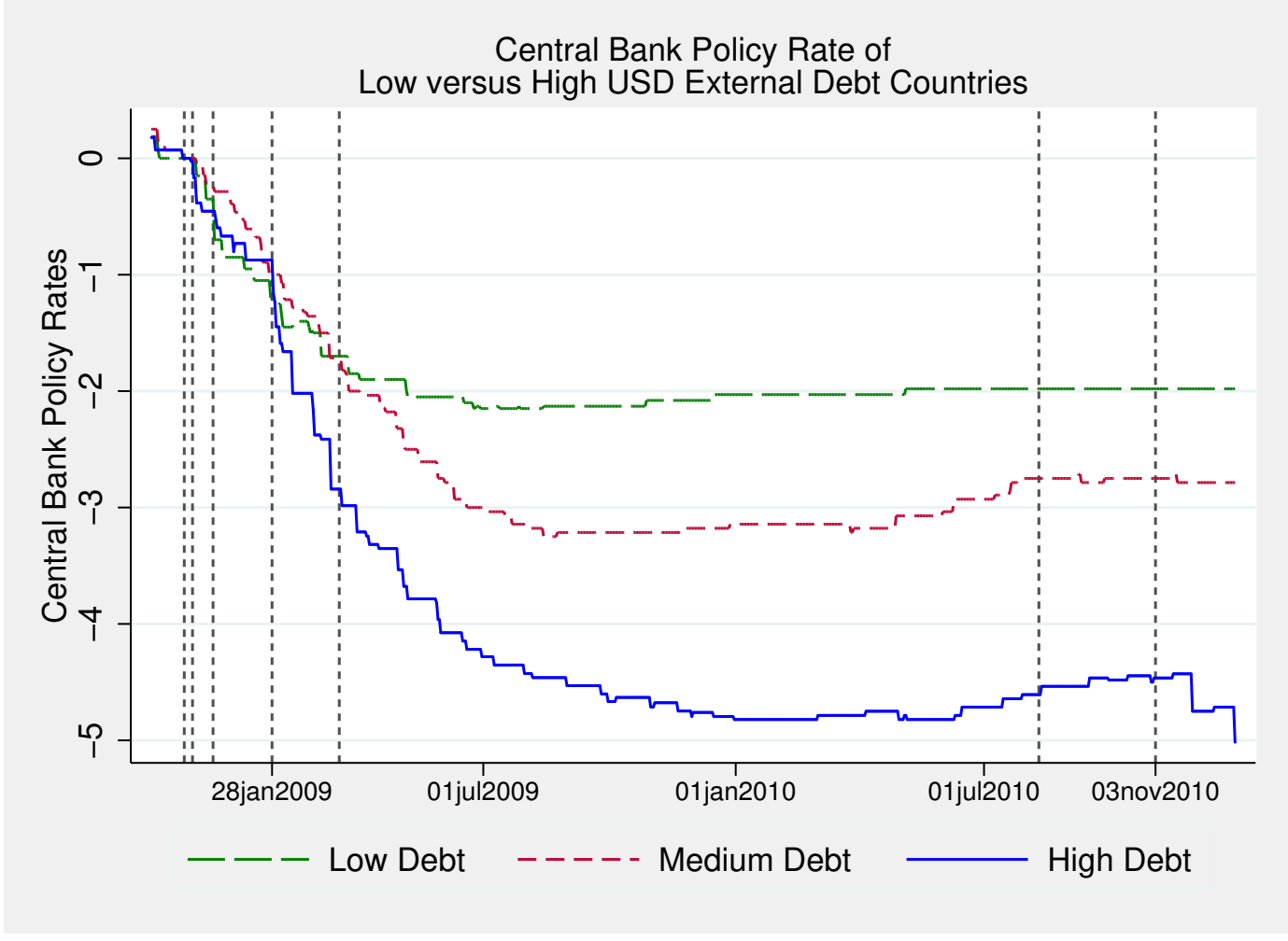

This figure plots foreign central banks' policy rates of low and high-USDebt countries from November 1, 2008, to December 30, 2010. The sample does not include Iceland. Countries are allocated to groups based on their USDebt in 2007. Policy rates of each portfolio are a simple average of its members'. Central bank policy rates are standardized to zero on November 25, 2008. Each vertical line indicates a QE announcement. The dates of QE I announcements are November 25, 2008, December 1, 2008, December 16, 2008, January 28, 2009, and March 18, 2009. The dates of QE II announcements are August 10, 2010, September 21, 2010, and November 3, 2010. 